\title{
Caracterización física y mecánica de morteros de cemento Portland fabricados con adición de partículas de poliestireno expandido (EPS)
}

\author{
Physical and mechanical characterization of Portland cement mortars \\ made with expanded polystyrene particles addition (EPS)
}

\author{
V. Ferrándiz-Mas(*), E. García-Alcocel ${ }^{*)}$
}

Recepción/Received: 3-VIII-11

Aceptación/Accepted: 23-I-12

Publicado online/Online publishing: 1-III-12

\section{RESUMEN}

El objetivo de este estudio es evaluar la influencia de la adición de distintos tipos y dosificaciones de poliestireno expandido, tanto comerciales como procedentes de reciclado, sobre las características físicas y mecánicas de morteros de cemento Portland. Las variables estudiadas fueron: consistencia, aire ocluido, densidad aparente, resistencias mecánicas, porosidad, absorción de agua y absorción acústica. Los morteros también se han caracterizado por microscopia electrónica de barrido. Con objeto de mejorar la trabajabilidad de los morteros se ha empleado aditivos aireante, retenedor de agua y fluidificante. Los resultados muestran que al aumentar la cantidad de poliestireno expandido la trabajabilidad y las resistencias mecánicas disminuyen. El empleo de aditivos mejora la trabajabilidad y la porosidad, permitiendo fabricar morteros con altos contenidos de residuo, con propiedades mecánicas adecuadas para su empleo como morteros de albañilería, revoco y enlucido.

Palabras clave: morteros, cemento, propiedades físicas y mecánicas, poliestireno expandido (EPS), residuo.

\section{SUMMARY}

On this work the influence of the addition of different types (commercial and recycled) and contents of expanded polystyrene on the physical and mechanical properties of Portland cement mortars has been studied. Variables studied are: workability, air content, bulk density, mechanical strength, porosity, water absorption and sound absorption. Mixtures have been also characterized by scanning electron microscopy. Airentraining agents, water retainer and superplasticizer additives have been used in order to improve the workability of mortars. The results show that the workability and mechanical strength decreases with increasing content of expanded polystyrene. Additives improve the workability and porosity, allowing manufacture mortars with high levels of recycled material that show mechanical properties suitable for use as masonry mortars, stucco and plaster.

Keywords: mortar, cement, physical and mechanical properties, expanded polystyrene (EPS), waste.

(*) Universidad de Alicante (Alicante, España). 


\section{INTRODUCCIÓN}

Una gestión sostenible de los recursos implica un menor consumo de materias primas y energía, así como la disminución de los residuos. Esto se puede lograr integrando los residuos en procesos productivos tales como su incorporación a materiales de construcción tradicionales. Estos nuevos materiales de construcción resultan ecológicamente más eficientes al permitir un ahorro de materias primas, de consumo energético asociado a la fabricación de los productos a los que sustituyen, así como la preservación de espacios naturales debido a una menor necesidad de explotación de recursos minerales. Distintos residuos agroindustriales y poliméricos están siendo estudiados (1-3).

La espuma de poliestireno expandido (EPS) representa el $0,1 \%$ del total de los residuos sólidos urbanos. Varias organizaciones y asociaciones del EPS de más de treinta países, entre los que se encuentra España, han suscrito un acuerdo internacional sobre el reciclado comprometiéndose a promover el uso del EPS reciclado en la más amplia gama de aplicaciones posibles.

EI EPS es un polímero termoplástico espumado con estructura celular cerrada. Es biológicamente inerte y no tóxico. El EPS posee interesantes propiedades tales como su baja densidad, aislamiento térmico, comportamiento hidrofóbico, y resistencia química a ácidos y álcalis. El EPS se puede encontrar en perlas, granulado en forma de pequeñas partículas. Las perlas de EPS se pueden considerar como un tipo de árido artificial de naturaleza polimérica, no absorbente y ultraligero (densidad menor de $\left.300 \mathrm{~kg} / \mathrm{m}^{3}\right)(4,5)$. Estos áridos permiten la fabricación de materiales de construcción ligeros.

Históricamente el hormigón ligero es usado tanto para aplicaciones no-estructurales como estructurales (6). Los hormigones ligeros fabricados con EPS se han utilizado en aplicaciones tales como paneles para revestimiento, muros cortina, sistemas para revestimiento de suelos compuestos y bloques de hormigón (7), como material para subbase de firmes de carreteras y vías de tren; para estructuras marinas flotantes, lechos y barreras marinas; como material absorbente de energía para la protección de estructuras militares sepultadas y como pantalla en las plataformas de petróleo (8-10).

La literatura en el campo del hormigón con EPS está principalmente dedicada a la caracterización de las propiedades mecánicas de estos materiales, tratando de mejorarlas utilizando EPS de diferentes granulometrías, aditivos y distintas adiciones como cenizas volantes y humo de sílice (11-13). Otros trabajos además de caracterizar térmica y mecánicamente el hormigón con EPS proponen métodos de modelización para predecir estas propiedades y optimizar la consecución de ambas simultáneamente (14). Artículos más

\section{INTRODUCTION}

A sustainable resource management means less consumption of raw materials and energy, just as waste reduction. This can be achieved by integrating waste in production processes such as integration of traditional building materials. These new building materials are environmentally more efficient by allowing a saving of raw materials, energy consumption associated with the manufacture of the products they replace, and the preservation of natural areas due to a reduced need for mineral resources. Different agri-food and polymeric waste are being studied (1-3).

Expanded polystyrene foam (EPS), represents $0,1 \%$ of total municipal solid waste. Various EPS organizations and associations from over thirty countries, among which is Spain, have signed an international agreement on recycling to promote the use of recycled EPS in the widest range of possible applications.

Expanded polystyrene foam (EPS) is a thermoplastic polymer closed cell structure. It is a biologically inert and nontoxic. EPS has interesting properties such as low density, thermal insulation, hydrophobicity and chemical resistance when exposed to acids and alkalis. EPS is granulated into small particles that can be considered as non-absorbent and lightweight polymeric aggregate (less than $300 \mathrm{~kg} / \mathrm{m}^{3}$ density) (4, 5). These aggregates allow the production of light building materials.

Historically, lightweight concrete is used for both nonstructural and structural uses (6). Lightweight concretes manufactured with EPS have been used as rendering panel, curtain walls, coating systems for composite flooring and concrete blocks (7), as a sub-basis material in road pavement and railways; in sea floating structures, marine beds and barriers; as energy absorbent material for military buried structures protection and as screens in petrol platforms (8-10).

The literature in the field of concrete with EPS is especially about the characterization of the mechanical properties of these materials, trying to improve those using EPS of different grain sizes, additives and other additions such as fly ash and silica fume (11-13). Other studies characterize the mechanical and thermal EPS concrete properties. In addition, these studies proposed modelling methods to predict and optimize these properties (14). 
recientes revelan las adecuadas propiedades en estado fresco de hormigones estructurales ligeros con propiedades autocompactantes fabricados con EPS y nano- $\mathrm{SiO}_{2}$ (15).

Otras líneas de trabajo utilizan perlas de EPS para diseñar composites aislantes térmicos fabricados con pastas de cemento espumadas, como matriz, y gránulos de poliestireno espumado como fílleres usando aditivos que impidan la segregación y mejoren la adherencia (16). El EPS también se ha utilizado con matriz de escayola reforzada con fibras de polipropileno para la fabricación de elementos industrializados (17) y con mezclas de ceniza volante y metacaolinita para la obtención de materiales poliméricos inorgánicos ligeros (geopolímeros ligeros) (18).

Sin embargo, no se han encontrado referencias bibliográficas que contengan estudios científicos del uso del EPS para la fabricación de morteros de cemento Portland, tanto de albañilería como especiales. Por el contrario, sí se pueden encontrar morteros comerciales con adición de perlas de poliestireno de tamaño superior a $3 \mathrm{~mm}$ para algunas aplicaciones determinadas. Por tanto, el objetivo de este trabajo es analizar las características diferenciadoras que aporta la adición de distintos tipos de EPS, tanto comerciales como procedentes de reciclado, a morteros de cemento Portland. Para ello se evaluarán las propiedades físicas y mecánicas del mortero, con el fin de demostrar que cumplen los requisitos mecánicos establecidos por la normativa para morteros de enlucido, revoco y albañilería.

\section{MATERIALES Y MÉTODOS}

\subsection{Materiales y preparación de los morteros}

Para la fabricación de los morteros estudiados se han empleado los siguientes materiales: cemento Portland CEM I 52.5R, arena silícea normalizada cumpliendo con la norma europea UNE-EN 196-1:2005 (19), agua destilada, EPS de distintas tipologías, así como tres tipos de aditivos.

La Tabla 1 muestra los óxidos que se encuentran en cantidades superiores al $0,1 \%$ en el análisis químico del cemento utilizado.

Los distintos tipos de EPS utilizados son: poliestireno expandido (EPSg), poliestireno prexpandido (EPSp), residuo limpio de poliestireno expandido triturado (EPStr) y
Recent articles show adequate fresh properties of concrete self-compacting lightweight structural made nano-SiO 2 and EPS (15).

Other works used EPS beads to design thermal insulator composites made with foamed cement pastes, using additives to prevent segregation and improve adherence (16). The EPS has also been used in plaster reinforced with polypropylene fibres for the manufacture of industrial components (17) and in mixtures of fly ash and metakaolinite to obtain light inorganic polymeric materials (light geopolymers) (18).

However, no bibliographic references have been located to prove the existence of scientific studies regarding its use in brickwork and special mortars production. On the other hand, there are commercialized mortars with more than $3 \mathrm{~mm}$ pearls EPS additions for some specific uses. The main aim of this study is to evaluate the influence of the addition of EPS, of both commercial and recycling, in Portland cement mortars. Physical and mechanical properties of mortars made with different types and percentage of EPS were studied. These mortars comply with the mechanical requirements established by the regulations for plastering mortar, plaster and masonry.

\section{EXPERIMENTAL}

\subsection{Materials and samples preparation}

The following materials were used for this study: Portland cement type CEM I 52,5R, silica sand according to EN 196-1:2005 (19), distilled water, different types of $E P S$, and three additives types.

Oxides that are in amount bigger than $0.1 \%$ in Portland cement used are given in table 1.

The following types of EPS were used: commercial expanded polystyrene (EPSg), pre-expanded polystyrene (EPSP), grinding expanded polystyrene from clean waste

Tabla 1 / Table 1

Composición química del cemento utilizado. Chemical analysis of Portland cement.

\begin{tabular}{|c|c|c|c|c|c|c|c|c|c|c|}
\hline$\%$ & $\mathrm{CaO}$ & $\mathrm{SiO}_{2}$ & $\mathrm{Al}_{2} \mathrm{O}_{3}$ & $\mathrm{Fe}_{2} \mathrm{O}_{3}$ & $\mathrm{SO}_{3}$ & $\mathbf{M g O}$ & $\mathrm{K}_{2} \mathrm{O}$ & $\mathrm{Na}_{2} \mathrm{O}$ & $\mathrm{TiO}_{2}$ & $\mathrm{SrO}$ \\
\hline $\mathrm{CEM} \mathrm{I} 52,5 \mathrm{R}$ & 65.32 & 18.16 & 4.34 & 3.24 & 4.04 & 2.89 & 0.99 & 0.34 & 0.22 & 0.15 \\
\hline
\end{tabular}


residuo limpio de poliestireno expandido en polvo (EPSpv), ambos procedentes de reciclado. En todos los casos el material utilizado es de color blanco, con una pérdida por ignición del $100 \%$, temperatura de reblandecimiento comprendida entre 80 y $100^{\circ} \mathrm{C}$, y absorción de agua por inmersión, después de 28 días, comprendida entre el 1 y $3 \%$ en volumen (20). La Tabla 2 muestra otras propiedades que diferencian los distintos tipos de EPS.

Los tres tipos de aditivos empleados fueron: aditivo aireante (A), Basf Rheomix 934, aditivo retenedor de agua $(R)$, Hidroxipropil metil celulosa y aditivo fluidificante $(F)$, Basf Rheomix GT 205 MA.

Los morteros se han preparado empleando dosificación en peso normalizada 1:3:0.5. Todos los morteros estudiados se han fabricado empleado las siguientes cantidades fijas de los materiales en cada amasada: $450 \mathrm{~g}$ de cemento CEM I 52,5R, $1.350 \mathrm{~g}$ de arena silícea de densidad $1,67 \mathrm{~g} / \mathrm{cm}^{3}$ y $225 \mathrm{~g}$ de agua. Sobre estas cantidades fijas se dosificó el EPS como porcentaje de adición en volumen total del mortero, considerando como tal el volumen aparente de la arena ( $\mathrm{v} / \mathrm{v} \%)$. En los morteros con aditivos, tanto para establecer la cantidad de EPS como la cantidad de aditivo a dosificar, se empleó el ensayo de consistencia del mortero fresco por la mesa de sacudidas, según la norma UNE-EN 1015-3:2007 (21). Los aditivos se adicionaron en tres concentraciones distintas. Estas dependen del tipo de EPS con el que se esté trabajando, debido a la influencia observada en los morteros sin aditivos del tamaño y forma de las partículas de EPS sobre la trabajabilidad del mortero. La cantidad de aditivo se añadió a los morteros como porcentaje en peso sobre el peso de cemento (w/w\%). La Tabla 3 muestra las dosificaciones, expresadas en porcentaje (\%) y en peso ( $\mathrm{g})$, de EPS y aditivo utilizadas.

Los morteros fueron amasados según la norma UNE-EN 196-1:2005 (19) realizando una modificación en el proceso de compactación. Los morteros fabricados con EPSg y EPSp, concretamente con contenidos de $70 \%$ sin aditivos y con porcentajes superiores al $70 \%$ usando aditivo fluidificante, presentaron problemas de heterogeneidad por flotabilidad de las partículas de EPS en la matriz de mortero debido a la disgregación producida por los
(EPStr) and powder expanded polystyrene from clean waste (EPSpv). In all cases EPS used is white, with a loss on ignition of $100 \%$, softening point between 80 and $100^{\circ} \mathrm{C}$, and water absorption by immersion, after 28 days, between 1 and 3\% volume (20). Other properties of EPS particles are given in table 2.

The three types of additives used were: an air-entraining agent (A), Basf Rheomix 934, a water retainer additive $(R)$, Hidroxipropil metil cellulose and a superplasticizer additive (F), Rheomix GT 205 MA.

Mortars with a cement/sand/water ratio (by weight) of 1:3:0.5 were prepared. All mortars studied were prepared with the following amounts of materials: $450 \mathrm{~g}$ of CEM I 52,5R, $1350 \mathrm{~g}$ of standardized siliceous sand with $1.67 \mathrm{~g} / \mathrm{cm}^{3}$ density and $225 \mathrm{~g}$ of distilled water. EPS was dosed as addition percentage of total mortar volume, considering as such the apparent volume of sand $(v / v \%)$. The test of mortar workability by determination of consistence of fresh mortar by flow table according to EN 1015-3:2007 (21) was used to determine the EPS and additive amounts. Additives were added in three different concentrations according to the EPS types. It is due to size and shape EPS particles influence in workability of mortars without additives. Additives were added to mortars as a percentage of the weight of the cement (w/w \%). The table 3 shows EPS and additive dosages used, by percentage (\%) and weight (g).

Mortars were manufactured according to EN-196-1:2005 (19), making a modification in consolidation mechanical process. Mortars containing EPSg and EPSp, with $70 \%$ of EPS without additives and amount higher of $70 \%$ of EPS with superplasticizer additive showed segregation problems, due to low density of EPS particles. In order to avoid this problem, all mortars were consolidated with tamping rod in two layers. The $4 \times 4 \times 16 \mathrm{~cm}$ prismatic

Tabla 2 / Table 2

Propiedades de los distintos tipos de EPS utilizados en los morteros preparados. Properties of different EPS types used in mortars preparation.

\begin{tabular}{|c|c|c|c|c|}
\hline Tipo de EPS / EPS type & Reciclado / Waste & $\begin{array}{l}\text { Diámetro de partícula / } \\
\text { Particle diameter ( } \mathrm{mm} \text { ) }\end{array}$ & $\begin{array}{c}\text { Geometría de partícula / } \\
\text { Particle geometry }\end{array}$ & Densidad / Density $\left(\mathrm{g} / \mathrm{cm}^{3}\right)$ \\
\hline EPSg & No / No & $>3$ & Esférica / Spherical & 0.0076 \\
\hline EPSp & No / No & $<3$ & Esférica / Spherical & 0.052 \\
\hline EPStr & Sí / Yes & $<1$ & Irregular / Irregular & 0.013 \\
\hline EPSpv & Sí / Yes & Polvo / Powder & Irregular / Irregular & 0.022 \\
\hline
\end{tabular}


Tabla 3 / Table 3

Dosificación de EPS y aditivos en los morteros estudiados. EPS and additives dosage in studied mortars.

\begin{tabular}{|c|c|c|c|c|}
\hline Tipo de EPS / EPS type & EPS (v/v\%) (g) & $A^{a}(w / w \%)(g)$ & $R^{b}(w / w \%)(g)$ & $F^{c}(w / w \%)(g)$ \\
\hline \multirow{2}{*}{ EPSg } & $\begin{array}{c}0,10,30,50,70 \\
(0 ; 0.61 ; 1.84 ; 3.07 ; 4.30) \\
\end{array}$ & 0 & 0 & 0 \\
\hline & $\begin{array}{c}0,50,70,90 \\
(0 ; 3.07 ; 4.30 ; 5.53)\end{array}$ & $\begin{array}{c}0,5 ; 0,8 ; 1,1 \\
(2.25 ; 3.60 ; 4.95)\end{array}$ & $\begin{array}{c}0,1 ; 0,2 ; 0,3 \\
(0.45 ; 0.90 ; 1.35)\end{array}$ & $\begin{array}{c}0,1 ; 0,2 ; 0,3 \\
(0.45 ; 0.90 ; 1.35)\end{array}$ \\
\hline \multirow{2}{*}{ EPSp } & $\begin{array}{c}0,10,30,50,70 \\
(0 ; 4.20 ; 12.61 ; 21.02 ; 29.43)\end{array}$ & 0 & 0 & 0 \\
\hline & $\begin{array}{c}0,50,70,80 \\
(0 ; 21.02 ; 29.43 ; 33.63)\end{array}$ & $\begin{array}{c}0,8,1,5 ; 2 \\
(3.60 ; 6.75 ; 9.00)\end{array}$ & $\begin{array}{c}0,1 ; 0,2 ; 0,3 \\
(0.45 ; 0.90 ; 1.35)\end{array}$ & $\begin{array}{c}0,7 ; 0,8 ; 0,9 \\
(3.15 ; 3.60 ; 4.05)\end{array}$ \\
\hline \multirow{2}{*}{ EPStr } & $\begin{array}{c}0,10,30,50,70 \\
(0 ; 1,05 ; 3,15 ; 5,26 ; 7,36)\end{array}$ & 0 & 0 & 0 \\
\hline & $\begin{array}{c}0,50,60,70 \\
(0 ; 5.26 ; 6.31 ; 7.36)\end{array}$ & $\begin{array}{c}0,5 ; 0,8 ; 1 \\
(2.25 ; 3.60 ; 4.50)\end{array}$ & $\begin{array}{c}0,1 ; 0,2 ; 0,3 \\
(0.45 ; 0.90 ; 1.35)\end{array}$ & $\begin{array}{c}0,4 ; 0,5 ; 0,6 \\
(1.80 ; 2.25 ; 2.70)\end{array}$ \\
\hline EPSpv & $\begin{array}{c}0,10,30,50,70 \\
(0 ; 1.78 ; 5.33 ; 8.89 ; 12.45)\end{array}$ & 0 & 0 & 0 \\
\hline
\end{tabular}

aA: Aditivo aireante / Air entraining agent, bR: Aditivo retenedor de agua / Water retainer additive; cF: Aditivo fluidificante / Superplasticizer additive.

golpes en la compactación con la compactadora mecánica. Por ello y con el fin de conseguir morteros homogéneos, todos los morteros fabricados, independientemente del tipo de EPS y del tipo de aditivo, se compactaron mediante picado manual en dos capas. Las probetas prismáticas de $4 \times 4 \times 16 \mathrm{~cm}$ fueron curadas bajo agua a una temperatura de $20 \pm 2^{\circ} \mathrm{C}$. Aunque las edades de curado para los ensayos en estado endurecido fueron de 7, 28 y 120 días, se muestran exclusivamente los resultados a 120 días por considerar que a esta edad el mortero habrá prácticamente finalizado su proceso de endurecimiento presentando unas características más estables, lo que permite observar mejor la influencia de la presencia del EPS en las propiedades del mismo. Las probetas empleadas para los ensayos de acústica fueron probetas cilíndricas de $34,5 \mathrm{~mm}$ de diámetro y $40 \mathrm{~mm}$ de altura, y se curaron durante 28 días bajo agua.

\subsection{Ensayos}

\section{Propiedades en estado fresco}

En estado fresco se determinó la consistencia de los morteros mediante la mesa de sacudidas (UNE-EN 10153:2007) (21), el aire ocluido (UNE-EN 1015-7:1999) (22), así como la densidad aparente del mortero fresco (UNE-EN 1015-6:1999/A1:2007) (23). El ensayo de consistencia se considera como una medida de la fluidez $y / 0$ de la humedad del mortero fresco. Proporciona información de la deformabilidad o trabajabilidad del mortero fresco cuando se somete a un determinado tipo de esfuerzo. Por ello, además de caracterizar las propiedades del mortero fresco, se ha utilizado como ensayo previo para establecer la cantidad de EPS y de aditivo a dosificar en los morteros. specimens were cured in water under laboratory conditions at $20 \pm 2{ }^{\circ} \mathrm{C}$. The curing time of specimens was 7, 28 and 120 days, but on this work we are showing only results at 120 days due to at this time mortar shows stable characteristics. This fact allows to study the EPS influence in mortar properties better. Specimens used in acoustic test were cylindrical specimens of $34.5 \mathrm{~mm}$ in diameter and $40 \mathrm{~mm}$ height. These specimens were cured under water during 28 days.

\subsection{Test}

\section{Fresh Properties}

In fresh mortar was determined consistence by the flow table method according to EN 1015-3:2007 (21), air content according to EN 1015-7:1999 (22) and bulk density according to EN 1015-6:1999 / A1: 2007 (23). The consistence test is considered as a measure of fluidity and/or humidity of the fresh mortar. This test provides information on the fresh mortar workability when it is subjected to a certain type of effort. Therefore, in addition to characterize the properties of fresh mortar has been used as a preliminary test to establish the amount of EPS and additive dosing in mortars. 


\section{Propiedades en estado endurecido}

Se ha realizado la caracterización mecánica midiendo la resistencia a flexotracción y a compresión siguiendo la norma UNE-EN 196-1:2005 (19).

Utilizando porciones de las muestras ensayadas mecánicamente para cada una de las distintas edades de curado, se ha determinado la densidad aparente del mortero en estado endurecido siguiendo la norma UNE-EN 101510:2000 (24). Con los datos obtenidos, al aplicar la misma: masa de la muestra seca $\left(\mathrm{m}_{\mathrm{sec}}\right)$, masa de la muestra saturada $\left(m_{\mathrm{sat}}\right)$ y masa de la muestra sumergida en agua $\left(\mathrm{m}_{\mathrm{i}}\right)$, se ha calculado la porosidad abierta y la absorción de agua según las siguientes expresiones: porosidad abierta $(\%)=\left(\left(m_{\text {sat }}-m_{\text {sec }}\right) /\left(m_{\text {sat }}-m_{\mathrm{i}}\right)\right) \times 100$ y absorción de agua $(\%)=\left(\left(\mathrm{m}_{\mathrm{sat}}-\mathrm{m}_{\mathrm{sec}}\right) / \mathrm{m}_{\mathrm{sec}}\right) \times 100$. Estos ensayos, junto con los realizados en estado fresco, nos ayudan a caracterizar el mortero físicamente.

Los ensayos de caracterización acústica de las probetas se realizaron mediante la determinación experimental del coeficiente de absorción acústica a incidencia normal determinado mediante el tubo de impedancia o tubo de Kundt (25), método muy utilizado en el proceso de diseño de un material. Se emplearon probetas cilíndricas de mortero de $34,5 \mathrm{~mm}$ de diámetro por $40 \mathrm{~mm}$ de altura, curadas durante 28 días bajo agua a $20 \pm 2{ }^{\circ} \mathrm{C}$, y secadas después en la estufa a $65 \pm 2^{\circ} \mathrm{C}$ antes de ser ensayadas.

Para completar la caracterización del mortero, en algunos casos, se realizó un estudio morfológico mediante microscopía electrónica de barrido.

\section{RESULTADOS Y DISCUSIÓN}

La Tabla 4 muestra las propiedades en estado fresco estudiadas para los morteros fabricados sin aditivos. Los resultados muestran en todos los caso una correlación negativa entre el aumento en la dosificación del EPS y la consistencia. A partir de un $50 \%$ de EPS, se obtienen en todos los casos morteros secos, ya que el valor del escurrimiento

\section{Hardener properties}

Mechanical characterization was made by measure of flexural and compressive strength according to EN 1961:2005 (19).

Dry bulk density of hardened mortar was determinate according to EN 1015-10:2000 (24) using resulting pieces from the mechanical test for each curing age. With the dates obtained: dry mass $\left(m_{s e c}\right)$, saturated mass ( $\left.m_{\text {sat }}\right)$ and mass of the sample immersed in water $\left(m_{i}\right)$, open porosity and absorption water according to the following terms were calculated: open porosity $(\%)=\left(\left(m_{\text {sat }}-m_{\text {sec }}\right) /\left(m_{\text {sat }}-m_{i}\right)\right) \times 100$ and water absorption $(\%)=\left(\left(m_{\text {sat }}-m_{\text {sec }}\right) / m_{\text {sec }}\right) \times 100$. These tests, together with those made in fresh mortar, help to characterize it physically.

Acoustic characterization tests were made by the experimental determination of the absorption coefficient at normal incidence, using the impedance tube or Kundt tube (25). Cylindrical specimens of $34.5 \mathrm{~mm}$ in diameter by $40 \mathrm{~mm}$ height were used, cured for 28 days under water at $20 \pm 2{ }^{\circ} \mathrm{C}$ and then dried in an oven at $65 \pm 2{ }^{\circ} \mathrm{C}$ before being tested.

Finally, in some cases, a morphological study by scanning electron microscopy was made in order to complete the mortar characterization.

\section{RESULTS AND DISCUSSION}

Table 4 shows the fresh properties studied for mortars made without additives. The results show in all cases, a negative correlation between the increase in the EPS dosage and consistence. From 50\% EPS, dry mortars are obtained, with a spread in the flow table lower than $140 \mathrm{~mm}$. In case of EPSg dry mortars are obtained from

Tabla 4 / Table 4

Escurrimiento, aire ocluido y densidad del mortero en estado fresco (Dmf) de los morteros fabricados con distintos tipos y porcentajes de EPS sin aditivos (entre paréntesis desviación estándar).

Flow table spread, air content and bulk density of fresh mortar (Dmf) of the mortars made with different types and percentages of EPS without additives (standard deviation in parentheses).

\begin{tabular}{|c|c|c|c|c|c|c|c|c|c|c|c|c|c|c|c|}
\hline \multirow{2}{*}{ EPS (\%) } & \multicolumn{5}{|c|}{ Escurrimiento / Flow table spread $(\mathrm{mm})( \pm 7.9)$} & \multicolumn{5}{|c|}{ Aire ocluido / Air content $(\%)( \pm 1.5)$} & \multicolumn{5}{|c|}{$\operatorname{Dmf}\left(\mathrm{g} / \mathrm{cm}^{3}\right)( \pm 0.1)$} \\
\hline & $\mathbf{0}$ & 10 & 30 & 50 & 70 & 0 & 10 & 30 & 50 & 70 & 0 & 10 & 30 & 50 & 70 \\
\hline EPSg & \multirow{4}{*}{199} & 179 & 165 & 150 & 140 & \multirow{4}{*}{7} & 8 & 8.5 & 9 & 9.5 & \multirow{4}{*}{2.3} & 2.2 & 2 & 1.9 & 1.7 \\
\hline EPSp & & 168 & 143 & 120 & - & & 7.5 & 6.5 & 9 & 10 & & 2.1 & 1.9 & 1.7 & 1.5 \\
\hline EPStr & & 174 & 143 & 127 & - & & 7 & 9 & 12 & 13 & & 2.1 & 2 & 1.9 & 1.8 \\
\hline EPSpv & & 149 & 134 & 130 & - & & 7 & 10.8 & 11.7 & 16 & & 2.2 & 2.2 & 2 & 1.9 \\
\hline
\end{tabular}


obtenido es inferior a $140 \mathrm{~mm}$, excepto para el EPSg que se obtienen a partir del $70 \%$ y del EPSpv que se obtienen a partir del $30 \%$. Estos resultados son coherentes con el hecho de haber trabajado con dosificación de morteros normalizada, en los cuales se ha mantenido constante la cantidad de agua de amasado. Para un mismo volumen de adición de EPS, en el caso del EPSg, hay muchas menos partículas, la demanda de agua será menor siendo los morteros más trabajables.

Para todos los tipos de EPS utilizados, se observa un aumento del aire ocluido conforme aumenta la dosificación de EPS en el mortero. Sin embargo, se aprecian diferencias en el contenido de aire, en función de la geometría de la partícula de EPS. Así, para un mismo porcentaje de EPS, se observa cómo las partículas irregulares, EPStr y EPSpv, ocluyen más aire, tanto más cuanto mayor es la superficie específica de la partícula, como se observa para el EPSpv. En general, la trabajabilidad de un mortero se ve mejorada con el aumento del contenido en aire ocluido, sin embargo, en estos morteros, el aumento en el contenido de aire no puede contrarrestar la pérdida de trabajabilidad que supone tanto la presencia de EPS en el mismo como la distinta forma de las partículas.

La presencia de EPS en el mortero reduce significativamente su densidad en estado fresco. Las disminuciones más significativas en esta propiedad se alcanzan a partir del $50 \%$ de EPS. Respecto a la influencia del tipo de EPS, fijando el porcentaje de adición, se encuentra que los valores para los morteros con EPSp son claramente inferiores al resto a partir del $30 \%$. Esto se debe a que es el que mayor masa de EPS contiene para un mismo volumen de adición.

Se decide trabajar adicionando hasta un $70 \%$ para todos los tipos de EPS, a pesar de no haber obtenido una adecuada trabajabilidad para ciertos morteros, con la finalidad de obtener una referencia que permita comparaciones posteriores con morteros fabricados con aditivos.

La Tabla 5 muestra el escurrimiento $(\mathrm{mm})$ para los morteros fabricados con tres tipos de EPS, usando aditivos en tres dosificaciones para cada uno de ellos. En ella se puede observar cómo los aditivos provocan, por lo general, un aumento de la trabajabilidad, permitiendo obtener morteros con mayor porcentaje de adición de EPS (hasta un $90 \%$ de adición para el caso del EPSg). El aditivo aireante $(A)$ aumenta la trabajabilidad entre un 15 y un $40 \%$, dependiendo del tipo de EPS. El aditivo retenedor (R) de agua provoca un aumento de la viscosidad de la pasta que se traduce en una disminución drástica de la trabajabilidad. Incluso en morteros sin EPS, este aditivo provoca pérdidas en la trabajabilidad de entre un $12 \%$ y un $20 \%$. En el caso de trabajar con EPStr y retenedor, los valores de consistencia caen por debajo de $120 \mathrm{~mm}$ para
$70 \%$ EPS and for EPSpv from 30\% EPS. These results are consistent with the fact of working with standard dosage of mortars, in which the amount of mixing water has remained constant. In the case of EPSg for the same volume of EPS addition, there are fewer particles, and then, water demand is lower and mortars are more workable.

The air content increase with EPS amount in mortars, for all types of EPS used. However, differences were found in the air content, depending on the geometry of the EPS particle. Irregular particles, EPStr and EPSpv, generate more air, the more specific surface of the particle, as can be observed for the EPSpv. The workability of mortar is improved with increasing its air content. However, in these mortars, the increase in air content is not able to counteract the loss of workability due to the amount and geometry particle of EPS.

The bulk density mortar is significantly reduced by the presence of EPS. The most significant reductions are achieved in this property from $50 \%$ of EPS. Regarding to the influence of EPS type, for a constant EPS dosage, for EPSp, values from $30 \%$ are lower than the rest values. This is because it is the largest mass of EPS contain for the same volume of addition.

In order to obtain a reference for later comparison with mortars made with additives, mortars were made adding up to $70 \%$ for all types of EPS, despite some mortars did not have a adequate workability.

Table 5 shows the flow table spread $(\mathrm{mm})$ for mortars made with EPS three types, using additives in three dosages for each of them. It can be seen as additives generally cause an increase in workability. This behaviour allows obtaining mortars with higher EPS percentage (up to $90 \%$ EPSg addition). The air-entraining agent $(A)$ increases the workability between 15 and 40\%, depending on the EPS type. The water-retaining additive $(R)$ causes an increase in the paste viscosity and therefore decreases workability. Even in mortars without EPS, this additive causes loss of workability of between $12 \%$ and $20 \%$. For mortars made with EPStr and water retainer additive, flow table spread values fall below 120 $\mathrm{mm}$ for a $0.1 \%$ water retainer additive. This fact makes difficult mortar placing, being necessary combine it with 
un $0,1 \%$ de retenedor, lo cual complica su adecuada puesta en obra, siendo necesario combinarlo con otros aditivos para mantener una adecuada trabajabilidad. El fluidificante (F) mejora significativamente la trabajabilidad respecto a los morteros fabricados sin aditivos. Para el caso del EPSg esta se incrementa en un $35 \%$, un $68 \%$ para el EPSp y un 50\% para el EPStr, respecto a los mismos morteros sin aditivos.

La Tabla 6 muestra el aire ocluido y la densidad del mortero fresco para los morteros fabricados con tres tipos de EPS y aditivos en tres dosificaciones para cada uno de ellos. Dado que los valores obtenidos para estas propiedades y las pautas de comportamiento entre los tres tipos de EPS son similares, se comentan principalmente los resultados de los morteros fabricados con residuo de EPS (EPStr) lo que permite estudiar la posibilidad de su valorización mediante su incorporación al mortero. Fijándonos en el comportamiento que experimenta el aire ocluido de estos morteros, se puede observar cómo para una misma cantidad de aditivo el aire ocluido sufre pocos cambios al aumentar el contenido de EPS. Por otro lado, excepto para el aditivo fluidificante, la presencia de EPS en los morteros reduce el efecto del aditivo sobre esta propiedad. Este comportamiento es coherente con el hecho de que el EPS en el mortero dificulta la formación de las burbujas de aire rompiendo la conexión de la red de poros. El comportamiento de los morteros fabricados con aditivo fluidificante no permite extraer conclusión del efecto del EPS dado que los morteros sin EPS se pueden considerar líquidos y experimentaron segregación. other additives for maintain adequate workability. The superplasticizer additive (F) improves significantly the workability if it is compared to mortars made without additives. Mortars made with EPSg increases values a $35 \%$, a $68 \%$ for the EPSp and a $50 \%$ for EPStr, if they are compared to the same mortar without additives.

Table 6 shows the air content and bulk density for mortars made with three types of EPS and additives in three dosages for each of them. Since the values obtained for these properties and the behaviour showed among the three types of EPS are similar, results for mortars made with EPS waste (EPStr) are discussed mainly. This fact allows studying the feasibility of reusing these wastes in the manufacture of more environmentally-friendly mortars. Looking at the air content values of these mortars, it can be seen for the same amount of additive, that they undergoes little change with increasing EPS content. On the other hand, except for the superplasticizer additive, the presence of EPS in mortars reduces the effect of the additive on this property. This behaviour is consistent with the fact that EPS in the mortar makes the formation of air bubbles breaking the connection of the network of pores. The behaviour of the mortars made with superplasticizer additive does not permit conclusions of the effect of EPS because mortars without EPS can be considered like a liquid and undergo segregation.

Tabla 5 / Table 5

Escurrimiento de morteros fabricados con distintos tipos y porcentajes de EPS utilizando distintos porcentajes de aditivo (entre paréntesis desviación estándar).

Flow table spread of mortars made with different types and percentages of EPS using different percentages of additive (standard deviation in parentheses).

\begin{tabular}{|c|c|c|c|c|c|c|c|c|c|c|c|c|c|c|c|}
\hline \multicolumn{16}{|c|}{ Escurrimiento / Flow table spread $(\mathrm{mm})$} \\
\hline \multirow{2}{*}{\multicolumn{2}{|c|}{$\begin{array}{c}\text { Aditivo I } \\
\text { Additive } \\
\text { (\%) }\end{array}$}} & \multicolumn{4}{|c|}{$\begin{array}{c}\text { EPSg (\%) } \\
\mathrm{A}( \pm 4.3), \mathrm{R}( \pm 1.9), \mathrm{F}( \pm 4.5)\end{array}$} & \multirow{2}{*}{$\begin{array}{c}\text { Aditivo I } \\
\text { Additive } \\
\text { (\%) }\end{array}$} & \multicolumn{4}{|c|}{ EPSp (\%) A ( \pm 2.0$), R( \pm 3.2), F( \pm 8.1)$} & \multirow{2}{*}{$\begin{array}{c}\text { Aditivo I } \\
\text { Additive } \\
\text { (\%) }\end{array}$} & \multicolumn{4}{|c|}{$\begin{array}{c}\text { EPStr (\%) } \\
\text { A }( \pm 3.0), \mathrm{R}( \pm 4.5), \mathrm{F}( \pm 3.7)\end{array}$} \\
\hline & & 0 & 50 & 70 & 90 & & 0 & 50 & 70 & 80 & & 0 & 50 & 60 & 70 \\
\hline \multicolumn{2}{|c|}{0} & 199 & 150 & 140 & - & 0 & 199 & 120 & - & - & 0 & 199 & 127 & - & - \\
\hline \multirow{3}{*}{$A^{a}$} & 0.5 & 203.5 & 168.5 & 160.8 & 160.8 & 0.8 & $\begin{array}{l}196.8 \\
\end{array}$ & 161.7 & 145.2 & 141.3 & 0.5 & 203.5 & 166.7 & 157.5 & 156.2 \\
\hline & 0.8 & $\begin{array}{l}196.8 \\
\end{array}$ & 174.5 & 156.7 & 158.8 & 1.5 & 200 & $\begin{array}{l}163.3 \\
\end{array}$ & 151.8 & 146.8 & 0.8 & 196.8 & $\begin{array}{l}168.3 \\
\end{array}$ & $\begin{array}{ll}161.8 \\
\end{array}$ & 152.5 \\
\hline & 1.1 & 198.8 & 177.8 & 167.2 & 160.8 & 2 & 200.2 & 167.7 & 151.7 & 142.8 & 1 & 200.2 & 163.8 & 164.8 & 157.7 \\
\hline \multirow{3}{*}{$\mathbf{R}^{\mathbf{b}}$} & 0.1 & 174.2 & 149.2 & 139.8 & 134.3 & 0.1 & 174.2 & 123 & $<110$ & $<110$ & 0.1 & 174.2 & $<120$ & $<115$ & $<115$ \\
\hline & 0.2 & 162.2 & 145.3 & 138.2 & 134.2 & 0.2 & 162.2 & 125.7 & 113.7 & $<110$ & 0.2 & 162.2 & 134.7 & 128 & 121.2 \\
\hline & 0.3 & 160.3 & 141.3 & 138.3 & 131.2 & 0.3 & 160.3 & 130.2 & 117.7 & 111.5 & 0.3 & 160.3 & 128.3 & 124.7 & 120 \\
\hline \multirow{3}{*}{$\mathrm{Fc}^{\mathrm{c}}$} & 0.1 & 207.3 & 181.8 & 178 & 166 & 0.7 & 285.5 & 202.2 & 158.2 & 144.7 & 0.4 & 274 & 194.8 & 170.7 & 149 \\
\hline & 0.2 & 219.3 & 195.5 & 181.0 & 163.0 & 0.8 & $>280$ & 170.6 & 145.2 & 130 & 0.5 & $>280$ & 187.8 & 174.3 & 157 \\
\hline & 0.3 & 244.7 & 198.5 & 193.5 & 177.8 & 0.9 & $>280$ & 186 & 147.7 & 145.9 & 0.6 & $>280$ & 182.2 & 164.3 & 144 \\
\hline
\end{tabular}

aA: Aditivo aireante / Air entraining agent, bR: Aditivo retenedor de agua / Water retainer additive; cF: Aditivo fluidificante / Superplasticizer additive. 
Tabla 6 / Table 6

Aire ocluido y densidad del mortero fresco (Dmf) para morteros fabricados con distintos tipos y porcentajes de EPS y distintos porcentajes de aditivo (entre paréntesis desviación estándar).

Air content and bulk density of fresh mortar (Dmf) for mortars made with different types and percentages of EPS and different percentages of additive (standard deviation in parentheses).

\begin{tabular}{|c|c|c|c|c|c|c|c|c|c|c|c|c|c|c|c|}
\hline \multicolumn{16}{|c|}{ Aire ocluido / Air content (\%) } \\
\hline \multirow{2}{*}{\multicolumn{2}{|c|}{$\begin{array}{c}\text { Aditivo I } \\
\text { Additive (\%) }\end{array}$}} & \multicolumn{4}{|c|}{$\begin{array}{c}\text { EPSg (\%) } \\
A( \pm 1.2), R( \pm 0.9), F( \pm 0.5)\end{array}$} & \multirow{2}{*}{$\begin{array}{c}\text { Aditivo I } \\
\text { Additive } \\
\text { (\%) }\end{array}$} & \multicolumn{4}{|c|}{$\begin{array}{c}\text { EPSp (\%) } \\
\text { A }( \pm 3.7), \text { R }( \pm 0.8), F( \pm 0.3)\end{array}$} & \multirow{2}{*}{$\begin{array}{l}\text { Aditivo I } \\
\text { Additive } \\
\text { (\%) }\end{array}$} & \multicolumn{4}{|c|}{$\begin{array}{c}\text { EPStr (\%) } \\
\text { A }( \pm 1.8), \mathrm{R}( \pm 1.1), \mathrm{F}( \pm 1.1)\end{array}$} \\
\hline & & 0 & 50 & 70 & 90 & & $\mathbf{0}$ & 50 & 70 & 80 & & $\mathbf{0}$ & 50 & 60 & 70 \\
\hline \multicolumn{2}{|c|}{$\overline{0}$} & 7 & 9 & 9.5 & - & $\overline{0}$ & 7 & 9 & 10 & - & $\mathbf{0}$ & 7 & 12 & - & 13 \\
\hline \multirow{3}{*}{$A^{a}$} & 0.5 & 26 & 20 & 22 & 21 & 0.8 & 30 & 16.5 & 16 & 14 & 0.5 & 26 & 21 & 21 & 21.5 \\
\hline & 0.8 & 30 & 19 & 20 & 19.5 & 1.5 & 45 & 16.5 & 15 & 16.5 & 0.8 & 30 & 20 & 24.5 & 25 \\
\hline & 1.1 & 33 & 22.5 & 22 & 20 & 2 & 55 & 39 & 35 & 30 & 1 & 32 & 22.5 & 20 & 20 \\
\hline \multirow{3}{*}{$\mathbf{R}^{\mathbf{b}}$} & 0.1 & 13.5 & 13 & 12.5 & 12 & 0.1 & 13.5 & 9.5 & 11 & 10.5 & 0.1 & 13.5 & 13 & 12.5 & 14 \\
\hline & 0.2 & 19.5 & 14 & 14.5 & 14.5 & 0.2 & 19.5 & 12 & 12.5 & 13 & 0.2 & 19.5 & 14.5 & 14 & 15 \\
\hline & 0.3 & 18.5 & 14.5 & 14.5 & 14 & 0.3 & 18.5 & 13 & 12 & 12 & 0.3 & 18.5 & 16 & 16 & 16.5 \\
\hline \multirow{3}{*}{$F^{c}$} & 0.1 & 7.5 & 12.5 & 12 & 12 & 0.7 & 2.6 & 10 & 12.5 & 11.5 & 0.4 & 9.5 & 19 & 16.5 & 17.5 \\
\hline & 0.2 & 9 & 13 & 13.5 & 12.5 & 0.8 & 1.5 & 9.5 & 10.5 & 11 & 0.5 & 4.9 & 17 & 18 & 19.5 \\
\hline & 0.3 & 8.5 & 12.5 & 13.5 & 14 & 0.9 & 1 & 8.5 & 10 & 10.5 & 0.6 & 2 & 15 & 17.5 & 19 \\
\hline \multicolumn{16}{|c|}{$\operatorname{Dmf}\left(\mathrm{g} / \mathrm{cm}^{3}\right)$} \\
\hline \multirow{2}{*}{\multicolumn{2}{|c|}{$\begin{array}{c}\text { Aditivo I } \\
\text { Additive (\%) }\end{array}$}} & \multicolumn{4}{|c|}{$\begin{array}{c}\text { EPSg (\%) } \\
A( \pm 0.05) . \mathrm{R}( \pm 0.02) . \mathrm{F}( \pm 0.23)\end{array}$} & \multirow{2}{*}{$\begin{array}{l}\text { Aditivo / } \\
\text { Additive } \\
(\%)\end{array}$} & \multicolumn{4}{|c|}{$\begin{array}{c}\text { EPSp (\%) } \\
A( \pm 0.15) . R( \pm 0.02) . F( \pm 0.04)\end{array}$} & \multirow{2}{*}{$\begin{array}{l}\text { Aditivo I } \\
\text { Additive } \\
\text { (\%) }\end{array}$} & \multicolumn{4}{|c|}{$\begin{array}{c}\text { EPStr (\%) } \\
\text { A }( \pm 0.03) . \text { R }( \pm 0.03) . F( \pm 0.08)\end{array}$} \\
\hline & & 0 & 50 & 70 & 90 & & 0 & 50 & 70 & 80 & & 0 & 50 & 60 & 70 \\
\hline \multicolumn{2}{|c|}{0} & 2.25 & 1.88 & 1.73 & - & 0 & 2.25 & 1.72 & 1.47 & - & 0 & 2.25 & 1.91 & - & 1.80 \\
\hline \multirow{3}{*}{$A^{a}$} & 0.5 & 1.81 & 1.60 & 1.43 & 1.41 & 0.8 & 1.79 & 1.43 & 1.32 & 1.33 & 0.5 & 1.81 & 1.57 & 1.51 & 1.49 \\
\hline & 0.8 & 1.79 & 1.61 & 1.54 & 1.42 & 1.5 & 1.95 & 1.48 & 0.89 & 1.30 & 0.8 & 1.79 & 1.50 & 1.54 & 1.48 \\
\hline & 1.1 & 1.83 & 1.62 & 1.45 & 1.42 & 2 & 2.26 & 1.49 & 1.39 & 1.33 & 1 & 1.90 & 1.55 & 1.51 & 1.49 \\
\hline \multirow{3}{*}{$\mathbf{R}^{\mathbf{b}}$} & 0.1 & 2.09 & 1.79 & 1.68 & 1.60 & 0.1 & 2.09 & 1.71 & 1.61 & 1.45 & 0.1 & 2.09 & 1.84 & 1.82 & 1.75 \\
\hline & 0.2 & 1.96 & 1.71 & 1.62 & 1.53 & 0.2 & 1.96 & 1.63 & 1.54 & 1.46 & 0.2 & 1.96 & 1.76 & 1.75 & 1.81 \\
\hline & 0.3 & 1.94 & 1.69 & 1.63 & 1.53 & 0.3 & 1.94 & 1.63 & 1.55 & 1.50 & 0.3 & 1.94 & 1.75 & 1.71 & 1.72 \\
\hline \multirow{3}{*}{$F^{c}$} & 0.1 & 2.19 & 1.82 & 1.72 & 1.64 & 0.7 & 2.22 & 1.65 & 1.55 & 1.48 & 0.4 & 2.21 & 1.85 & 1.82 & 1.76 \\
\hline & 0.2 & 2.16 & 1.74 & 1.67 & 1.02 & 0.8 & 2.29 & 1.75 & 1.56 & 1.52 & 0.5 & 2.04 & 1.88 & 1.82 & 1.77 \\
\hline & 0.3 & 2.18 & 1.78 & 2.09 & 1.57 & 0.9 & 2.24 & 1.72 & 1.60 & 1.55 & 0.6 & 2.30 & 1.87 & 1.80 & 1.76 \\
\hline
\end{tabular}

a A: Aditivo aireante / Air entraining agent; b R: Aditivo retenedor de agua / Water retainer additive; c F: Aditivo fluidificante / Superplasticizer additive.

La presencia de aditivos en los morteros sin EPS reduce, en la mayoría de los casos, la densidad del mortero fresco, sin experimentar marcadas diferencias al modificar la concentración de un mismo tipo de aditivo. Sin embargo, existen diferencias entre los distintos aditivos, siendo las densidades mayores las de los morteros con fluidificante y las menores las de los morteros con aireante.

En presencia de EPS, ni el aditivo retenedor ni el fluidificante producen grandes diferencias en la densidad respecto a los mismos morteros sin aditivo. Sin embargo, con el aireante la densidad del mortero fresco se reduce significativamente, como era de esperar, pero no se observan diferencias al modificar la concentración del aditivo.

En la Figura 1 se muestra la resistencia a compresión a 120 días de curado, para los morteros fabricados con diferentes tipos y dosificaciones de EPS, sin aditivos, así
In most cases, the presence of additives in mortars without EPS reduced the bulk density mortar, showing no significant differences by changing the concentration for the same additive. However, there are differences between the different additives. The highest bulk densities are for mortars made with the superplasticizer additive and the lowest are for mortars with airentraining agent.

In the presence of EPS, neither the water retainer additive nor the superplasticizer additive produce large differences in bulk density compared to the same mortars without additive. However, with the airentraining agent bulk density is significantly reduced, but differences are not noticed by changing the additive concentration.

Figure 1 shows the compressive strength after 120 days of curing time, for mortars made with different types and dosages of EPS, without additives, and the error bands 
como las bandas de error calculadas como el intervalo de confianza para el $95 \%$ de probabilidad. La resistencia a compresión disminuye al incrementar el porcentaje de EPS en el mortero, y siempre es significativamente menor que la resistencia del mortero patrón. Esto es debido a que al aumentar la cantidad de EPS en el mortero, la densidad en estado endurecido disminuye, causando pérdidas en la resistencia a compresión. También contribuye a la bajada de resistencia mecánica la pérdida de trabajabilidad que se produce al aumentar la dosificación de EPS, obteniéndose morteros menos homogéneos y disgregados. Para todos los porcentajes estudiados se observan las mayores pérdidas con el EPSp.

Tomando como referencia un 50\% de EPS, cantidad esta que mantiene a los morteros con una adecuada trabajabilidad, se observa cómo para los morteros con EPSg, EPStr y EPSpv los valores de resistencia a compresión obtenidos no son significativamente distintos entre sí. El único que difiere es el mortero con EPSp, que debido a su menor densidad ofrece menores resistencias. Los morteros fabricados con $70 \%$ de adición ofrecen pérdidas de resistencias de hasta el $80 \%$ en el caso más desfavorable del EPSp. En cualquier caso, los valores alcanzados, si bien no son adecuados para los requerimientos mecánicos de los morteros convencionales, si lo son para los que se establecen en morteros para revocos y enlucidos (UNE-EN 998:1) (26) y morteros de albañilería (UNE-EN 998:2) (27), donde la resistencia a compresión a 28 días es inferior a $20 \mathrm{~N} / \mathrm{mm}^{2}$. En este sentido se podrían fabricar morteros con porcentajes de adición de hasta un $50 \%$ en todos los casos, dado que su resistencia a 28 días es de 26,8 $\pm 1,8$, $19,7 \pm 0,7,27,6 \pm 1,1$ y $19,4 \pm 1,0 \mathrm{~N} / \mathrm{mm}^{2}$ para el EPSg, EPSp, EPStr y EPSpv respectivamente y de hasta el $70 \%$ con EPSg, EPStr y EPSpv cuyos valores a 28 días son de $17,2 \pm 0,4,20,2 \pm 0,9$ y $13,9 \pm 2,3 \mathrm{~N} / \mathrm{mm}^{2}$, respectivamente. calculated as the confidence interval for the 95\% probability. The compressive strength decreased with increased percentage of EPS in the mortar, and is always significantly less than the strength of the control mortar. This is because increasing the amount of EPS in the mortar, the dry bulk density decreases, causing losses in compressive strength. The workability loss that occurs when increasing the EPS dosage, also contribute in the drop in mechanical strength. Less homogeneous and disintegrated mortars were obtained. For all mortars studied the highest losses are observed with the EPSP.

For mortars with a $50 \%$ EPS, amount that keeps adequate workability mortars, the compressive strength values obtained are not significantly different from each other for mortars with EPSg, EPStr and EPSpv. Only mortars with EPSp are different, due to its less dry bulk density offer a minor compressive strength. The mortars made with $70 \%$ EPS addition also show resistance losses of up to $80 \%$ in the worst case of EPSp. The compressive strength values obtain are not suitable for the mechanical requirements of conventional mortars. Nevertheless, these mortars meet the requirements of the EN 998:1 (26) and the EN 998:2 (27), for masonry, rendering and plaster mortars, in terms of nominal compressive strength, where requirements are below 20 $\mathrm{N} / \mathrm{mm}^{2}$. In consequently it might make mortars with EPS percentages up to $50 \%$ in all cases, because of 28 days compressive strength are $26.8 \pm 1.8,19.7 \pm 0.7,27.6 \pm$ 1.1 and $19.4 \pm 1.0 \mathrm{~N} / \mathrm{mm}^{2}$ for the EPSg, EPSp, EPStr and EPSpv respectively. And up to $70 \%$ with EPSg, EPStr EPSpv whose 28 days strength values are $17.2 \pm 0.4$, $20.2 \pm 0.9$ and $13.9 \pm 2.3 \mathrm{~N} / \mathrm{mm}^{2}$ respectively.

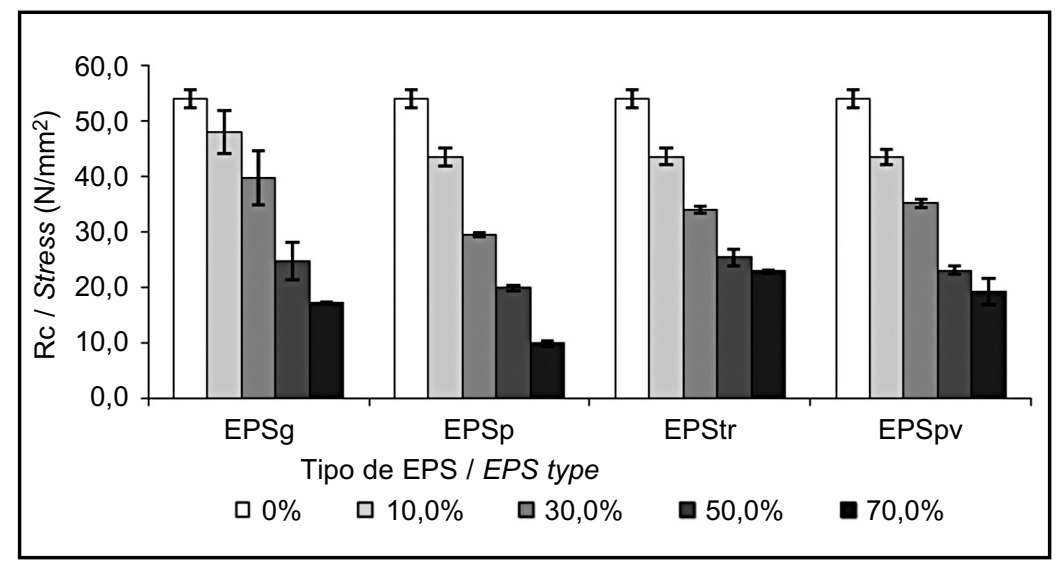

Figura 1. Resistencia a compresión (Rc) a 120 días en función del porcentaje y tipo de EPS, junto con el intervalo de confianza para el 95\% de probabilidad. Figure 1. 120 days compressive strength (Rc) as a function of the percentage and type of EPS in mortar, with the $95 \%$ confidence interval. 
La Figura 2 muestra las resistencias a compresión, a 120 días de curado, expresada como la relación entre la resistencia del mortero con EPS y aditivo (Rci) entre el valor de resistencia obtenido para el mortero patrón, $0 \%$ EPS y $0 \%$ aditivo (Rco). La Figura $2 \mathrm{~A}$ muestra los datos de los morteros fabricados con aditivo aireante $(A)$. Se puede observar que la adición de aditivo aireante a los morteros que no contienen EPS reduce la resistencia alrededor de un $65 \%$. En los morteros con 50 y $70 \%$ de EPS y aireante la resistencia cae alrededor de un $85 \%$ respecto al mortero patrón. Dentro de los morteros que contienen EPS y aireante, la resistencia cae aproximadamente un $30 \%$ respecto al mortero con el mismo \% EPS sin aditivo. El comportamiento de las resistencias mecánicas en morteros con aditivo retenedor ( $R$ ) aparece en la Figura 2B. En ella se observa cómo la resistencia también disminuye al añadir aditivo retenedor a morteros sin
Figure 2 shows 120 days compressive strength, expressed as a fraction of the compressive strength value found for the control mortar (Rci/Rco), where Rci is the strength of EPS with additive mortars and Rco is the strength for the control mortar (0\% EPS and 0\% additive). Figure $2 A$ shows the data of the mortars made with air-entraining agent $(A)$. It can be seen that the addition of air-entraining agent to 0\%EPS mortars reduces about $65 \%$ their compressive strength. In mortars with 50 and $70 \%$ of EPS the compressive strength falls around $85 \%$ compared to the control mortar. Within the mortars containing EPS and airentraining agent, the resistance falls about 30\% compared to the mortar with the same amount of EPS without additive. Figure $2 B$ shows the behaviour of mortars made with water retainer additive $(R)$. It is seen that in $0 \%$ EPS mortars, the compressive strength

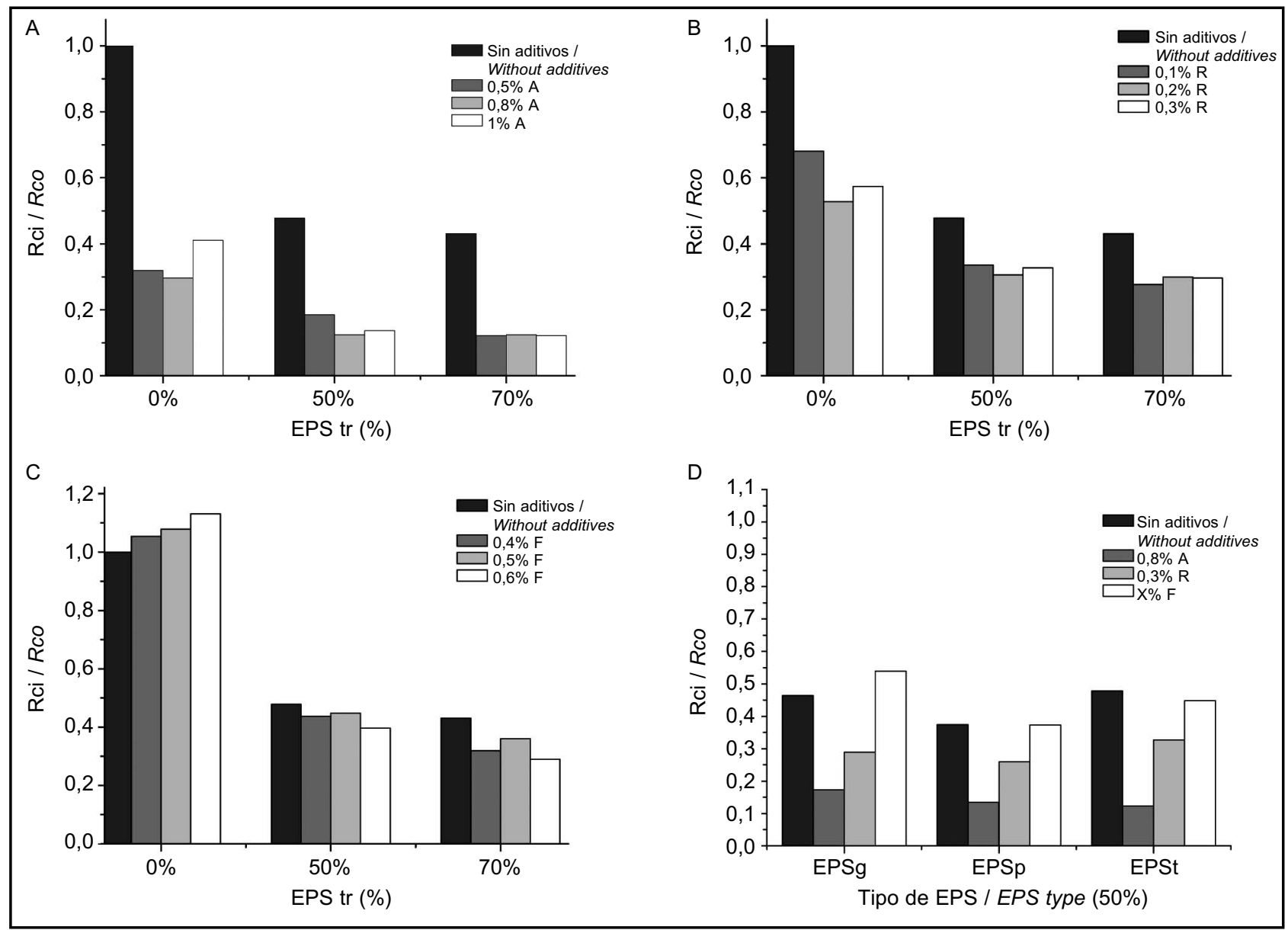

Figura 2. Resistencia a compresión a 120 días de curado expresada como relación Rci/Rco (Rci: Resistencia a compresión para un mortero dado; Rco: Resistencia a compresión para el mortero patrón. (0\% EPS. 0\% aditivos)). A) Morteros fabricados con EPStr y aditivo aireante (A). B) Morteros fabricados con EPStr y aditivo retenedor (R). C) Morteros fabricados con EPStr y aditivo fluidificante (F). D) Morteros fabricados con $50 \%$ de diferentes tipos de EPS y aditivos siendo el valor X\% F de 0,1\% para EPSg, 0,9\% para EPSp y $0,5 \%$ para EPStr.

Figure 2. 120 days compressive strength expressed as a ratio Rci/Rco (Rci: Compressive strength for a given mortar. Rco: Compressive strength for control mortar. (0\% EPS. $0 \%$ additive)). A) Mortars made with EPStr and air-entraining agent (A). B) Mortars made with EPStr and water retainer additive (R). C) Mortars made with EPStr and superplasticizer additive (F).D) Mortars made with different EPS types and additives. In all cases 50\% EPS dosage was used. The value of X\% F is $0.1 \%$ for EPSg $0.9 \%$ for EPSP and $0.5 \%$ for EPStr. 
EPS quedando reducida alrededor de un $40 \%$. En los morteros con 50 y $70 \%$ de EPS y retenedor la resistencia cae alrededor de un $70 \%$ respecto al mortero patrón. Las pérdidas son tan solo de un $15 \%$ para los morteros con EPS al añadir el retenedor respecto al mortero con el mismo \% EPS sin aditivo. En la Figura 2C, se muestra la variación en la resistencia para los morteros con fluidificante (F). Este aditivo, a diferencia del aireante y el retenedor, no produce una disminución de la resistencia en morteros sin EPS, provocando un incremento de aproximadamente un $10 \%$. La resistencia de los morteros con EPS y fluidificante disminuye alrededor de un $60 \%$ respecto al mortero patrón, mientras que respecto al mismo mortero sin aditivo las disminuciones son de un $5 \%$ para morteros con $50 \%$ de EPS y un $10 \%$ para morteros con $70 \%$ de EPS. Con los tres aditivos se observa que existen pocas variaciones en la resistencia a compresión de los morteros tanto en función de la cantidad de EPS como de aditivo con la que estemos trabajando. En todos los casos, el comportamiento del aditivo queda claramente influenciado por la presencia de EPS en el mortero. La Figura 2D muestra la resistencia a compresión de morteros con aditivo y $50 \%$ de adición de los distintos tipos de EPS estudiados. Se observa que el único aditivo que consigue mantener la resistencia respecto al mortero con EPS sin aditivo es el fluidificante, excepto para el EPStr. El aireante siempre produce una disminución en la resistencia, mientras que el retenedor presenta un comportamiento intermedio entre ambos aditivos. Con el aireante no se establecen diferencias entre las tipologías de EPS estudiadas, siendo en todos los casos las pérdidas superiores al $85 \%$ respecto al patrón, y atribuibles al exceso de aire ocluido por el aditivo. Con el fluidificante se observan pérdidas de resistencia cercanas al $65 \%$ para el EPSg y EPStr, mientras que con el EPSp las pérdidas son de un $75 \%$ respecto al mortero patrón. Esta diferencia del $10 \%$ se puede atribuir a las mismas razones comentadas anteriormente para este tipo de EPS. Con el retenedor se observan caídas de resistencias intermedias, próximas al $70 \%$, respecto a las observadas para el aireante y el fluidificante. Por tanto, para un mismo tipo de aditivo, no se detecta una influencia clara del tipo de EPS, lo que justifica que en este artículo se muestren principalmente los resultados para los morteros fabricados con residuo (EPStr).

La Tabla 7 muestra la densidad aparente en estado endurecido, la resistencia a flexión y la absorción de agua para morteros fabricados con EPStr y los tres tipos de aditivos en distintas concentraciones, así como los valores obtenidos para el mortero patrón, todos ellos para una edad de 120 días. Respecto a la densidad aparente de los morteros en estado endurecido, se observa cómo la densidad del mortero patrón es mayor que las densidades de los morteros con EPS sin aditivos, sin detectar grandes diferencias al modificar la dosificación de EPS. decreases about $40 \%$ by addition of this additive. In mortars with 50 and $70 \%$ of EPS the compressive strength falls around $70 \%$ compared to the control mortar. For mortars with EPS, the losses are about 15\% by addition of additive. Figure $2 \mathrm{C}$ shows the variation in compressive strength to superplasticizer mortars ( $F$ ). This additive, in contrast to the air-entraining agent and the water retainer, not reduce the compressive strength of $0 \%$ EPS mortars, causing an increase about $10 \%$. The compressive strength for EPS with superplasticizer mortars decreases about $60 \%$ compared to the control mortar. However, compressive strength fall are $5 \%$ for mortars with $50 \%$ EPS and $10 \%$ for mortar with $70 \%$ of EPS, compared to the same mortar without additive. There are little variations in compressive strength of mortars made with the three types of additives studied, both in terms of the amount of EPS as additive. In all cases, the behaviour of the additive is clearly influenced by the presence of EPS in the mortar. Figure 2D shows the compressive strength of mortars with additive and $50 \%$ addition of the different types of EPS studied. It can be seen that, except for the EPStr, the only additive that is able to maintain the compressive strength in mortar is the superplasticizer additive, compared to EPS mortars without additive. The air-entraining agent always produces a decrease in compressive strength while the water retainer additive has an intermediate behaviour between the two additives. With air-entraining agent there are not differences between types of EPS studied. In all cases, the losses are higher than 85\% compared to control mortar. This fact is attributable to excess of air content produces by this additive. The superplasticizer causes losses in compressive strength, compared to the control mortar, about $65 \%$ for the EPSg and EPStr, while the losses are about $75 \%$ for the EPSp. This $10 \%$ difference can be attributed to the same reasons discussed above for this type of EPS. With the water retainer additive fall in compressive strength is close to $70 \%$, and is between the values observed for the other additives. Therefore, for the same type of additive, a clear influence of the type of EPS is not detected. For this reason, in this work only the results for EPStr mortars are shown.

Table 7 shows the dry bulk density, flexural strength and water absorption, at 120 days curing time, for mortars made with EPStr and different amount of the three types of additives. It can be seen that the dry bulk density for control mortar is higher than for EPS mortar without additive. High differences are not observed by modifying the amount of EPS. In mortars without EPS, only the airentraining agent reduces significantly the dry bulk density compared to control mortar. Changes are not observed with the modification in the amount of this 
Tabla 7 / Table 7

Densidad aparente en estado endurecido (Dme), resistencia a flexión (Rf) y absorción de agua para morteros fabricados con distintos porcentajes de EPStr y distintos porcentajes de aditivo a 120 días de curado (entre paréntesis desviación estándar).

Dry bulk density (Dme), flexural strength (Rf) and water absorption of mortars made with different percentages of EPStr and different percentages of additive after 120 days curing time (standard deviation in parentheses).

\begin{tabular}{|c|c|c|c|c|c|c|c|c|c|c|c|c|}
\hline \multirow{2}{*}{$\begin{array}{l}\text { \% EPStr } \\
\text { Aditivo I } \\
\text { Additive }\end{array}$} & \multicolumn{4}{|c|}{$\begin{array}{c}\text { Dme }\left(\mathrm{g} / \mathrm{cm}^{3}\right) \\
\text { A }( \pm 0.06) . \mathrm{R}( \pm 0.04) . \mathrm{F}( \pm 0.04)\end{array}$} & \multicolumn{4}{|c|}{$\begin{array}{c}\mathrm{Rf}(\mathrm{MPa}) \\
\mathrm{A}( \pm 0.12) . \mathrm{R}( \pm 0.08) . \mathrm{F}( \pm 0.06)\end{array}$} & \multicolumn{4}{|c|}{$\begin{array}{c}\text { Absorción / Absorption (\%) } \\
\text { A }( \pm 0.25) . \mathrm{R}( \pm 0.09) . \mathrm{F}( \pm 0.28)\end{array}$} \\
\hline & 0 & 50 & 60 & 70 & 0 & 50 & 60 & 70 & 0 & 50 & 60 & 70 \\
\hline $0 \%$ & 1.99 & 1.76 & - & 1.63 & 1.87 & 1.35 & - & 1.11 & 6.66 & 7.59 & - & 8.20 \\
\hline $0.5 \% A^{a}$ & 1.66 & 1.43 & 1.36 & 1.37 & 0.74 & 0.77 & 0.69 & 0.60 & 8.60 & 8.94 & 9.30 & 9.35 \\
\hline $0.8 \% A^{a}$ & 1.64 & 1.34 & 1.38 & 1.31 & 0.81 & 0.63 & 0.68 & 0.61 & 8.83 & 9.59 & 9.13 & 9.50 \\
\hline $1 \% A^{a}$ & 1.75 & 1.40 & 1.35 & 1.35 & 1.29 & 0.62 & 0.63 & 0.61 & 8.19 & 9.40 & 9.54 & 9.57 \\
\hline $0.1 \% R^{b}$ & 1.88 & 1.66 & 1.63 & 1.60 & 1.38 & 1.00 & 1.02 & 0.91 & 7.99 & 8.21 & 8.10 & 8.28 \\
\hline $0.2 \% R^{b}$ & 1.80 & 1.64 & 1.58 & 1.58 & 1.34 & 0.92 & 0.92 & 1.01 & 8.42 & 8.54 & 8.62 & 8.64 \\
\hline $0.3 \% R^{b}$ & 1.79 & 1.57 & 1.55 & 1.53 & 1.35 & 1.06 & 0.94 & 0.90 & 9.01 & 9.01 & 9.16 & 9.38 \\
\hline $0.4 \% \mathrm{Fc}^{\mathrm{c}}$ & 2.07 & 1.65 & 1.63 & 1.57 & 2.02 & 1.21 & 1.22 & 1.12 & 7.52 & 7.98 & 7.99 & 8.32 \\
\hline $0.5 \% \mathrm{Fc}^{\mathrm{c}}$ & 2.11 & 1.69 & 1.66 & 1.59 & 2.12 & 1.25 & 1.29 & 1.07 & 7.12 & 8.46 & 7.92 & 8.83 \\
\hline $0.6 \% \mathrm{Fc}^{\mathrm{c}}$ & 2.16 & 1.72 & 1.64 & 1.60 & 1.99 & 1.10 & 1.03 & 0.95 & 6.47 & 7.65 & 8.20 & 8.69 \\
\hline
\end{tabular}

a A: Aditivo aireante / Air entraining agent, b R: Aditivo retenedor de agua / Water retainer additive; c F: Aditivo fluidificante / Superplasticizer additive.

En los morteros sin EPS solo el aditivo aireante reduce claramente la densidad respecto al patrón, sin experimentar diferencias al modificar la concentración del mismo. En presencia de EPS, ni el aditivo retenedor ni el fluidificante producen marcadas diferencias en la densidad respecto a los mismos morteros sin aditivo. Sin embargo, con el aireante la densidad del mortero endurecido se reduce significativamente, como era de esperar, aproximadamente un $30 \%$. En general, para ninguno de los aditivos se observan diferencias al modificar la dosificación de EPS ni la concentración del aditivo. Los valores obtenidos para la densidad en estado endurecido son coherentes con las resistencias a compresión discutidas con anterioridad, donde los morteros con aditivo aireante ofrecían las menores resistencias. Los valores obtenidos para esta propiedad y las pautas de comportamiento con los otros tipos de EPS son similares.

En cuanto a la resistencia a flexión, fijándonos en los morteros que no contienen aditivos, se observa cómo la presencia del EPS reduce significativamente las resistencias a flexión, tanto más cuanto mayor es el porcentaje de EPS que contiene el mortero, de manera que para un $70 \%$ de EPS las pérdidas de resistencia respecto al mortero patrón son aproximadamente de un $40 \%$. Al adicionar aditivos al mortero patrón, se producen pérdidas de resistencia en el caso del aditivo aireante y retenedor, que oscilan entre el $20 \%$ y $60 \%$. Sin embargo, con el aditivo fluidificante, se consigue un aumento en la resistencia a flexión de un $10 \%$ respecto al mortero patrón. Para morteros con EPS, el uso de estos aditivos no consigue evitar las pérdidas de resistencia a flexotracción respecto al mortero patrón. Para el $70 \%$ de EPStr, el aireante provoca pérdidas del $45 \%$, y tanto el retenedor como el fluidificante consiguen mantener prácticamente additive. In the presence of EPS, neither the water retainer additive nor the superplasticizer additive produce large differences in bulk density compared to the same mortars without additive. However, with the air-entraining agent bulk density is significantly reduced about 30\%. There are not differences for any of the additives when the EPS or additive amount is changed. The results obtained for the dry bulk density are consistent with the values for compressive strengths discussed above. The values obtained for this property and patterns of behaviour with other types of EPS are similar.

In EPS mortars without additive, flexural strength is reduced significantly by increasing EPS dosage. The losses are about $40 \%$ for $70 \%$ EPS mortars, compared to control mortar. If additives are added to control mortar, losses in flexural strength about 20\% for airentraining agent and about $60 \%$ for water retainer can be observed. However, the superplasticizer additive increase the flexural strength in 10\% compared to control mortar. In EPS mortars, additives are not able to avoid the flexural strength losses, compared to control mortar. For $70 \%$ of EPStr, the air entraining agent causes losses of $45 \%$ in this property. Both, the water retainer additive and the superplasticizer, get to keep the flexural strength mortar compared to mortar without additives. This behaviour could be attributed to better adhesion between the EPS and the cement paste that provide these additives. In the flexural strength test of 
la resistencia respecto al mortero sin aditivos. Esto se podría atribuir a la mejor adherencia entre el EPS y la pasta que confieren estos aditivos. Se ha podido comprobar experimentalmente en las roturas a flexión de estas probetas que ofrecían resistencia a su separación tras detectar la prensa su rotura.

La última propiedad que se muestra en la Tabla 7 es la absorción de agua, expresada como porcentaje máximo de agua que puede absorber la muestra al someterse a saturación. Se puede observar un aumento de la absorción en los morteros que contienen EPS, el cual no es exclusivamente atribuible a la microestructura de la pasta. Esta afirmación se puede apoyar con las imágenes SEM de estos morteros, que se muestran en la Figura 3. En ella se observa que las partículas de poliestireno rotas presentes en las muestras empleadas para el ensayo ofrecen una superficie de huecos abiertos que contribuyen a aumentar la absorción. Se espera que el comportamiento frente a la absorción de estos morteros puestos en obra sea mejor que el observado en este ensayo.

En morteros sin EPS, el empleo de aditivos, aumenta la absorción de agua respecto al patrón. En morteros con EPS, el aditivo aireante es el que produce un mayor aumento de la absorción. Para el $70 \%$ de EPS, bajas concentraciones de retenedor y fluidificante consiguen mantener la absorción respecto a morteros con EPS sin aditivos. Por otro lado, también se observa cómo la presencia de EPS en los morteros con retenedor amortigua el aumento en esta propiedad.

La Figura 4 muestra la porosidad abierta a 120 días de curado, para los morteros fabricados con diferentes tipos the specimens it has been discovered that their offered resistance to separation after detecting the press their break.

The last property shown in Table 7 is the absorption of water, expressed as maximum percentage of water that can absorb the sample to undergo saturation. It can be seen an increased in water absorption of mortars with EPS. This rise is not exclusively attributable to the microstructure of the cement paste. This statement can be supported by SEM images of these mortars, shown in Figure 3. It can be seen that there are broken EPS particles in the sample. These particles have an open pore surface that increases the water absorption of the mortar. It is expected that the behaviour in the water absorption of these mortar in real conditions will be better than the one observed in this test.

In mortars without EPS, the use of additives, increases water absorption compared with control mortar. In mortars with EPS, the air-entraining agent is who produces the highest increase in water absorption. For $70 \%$ EPS mortars, a low concentration of water retainer and superplasticizer absorption get to keep water absorption regarding to EPS mortars without additives. On the other hand, also observed that the presence of EPS in mortars with water retainer additive minimize the increase in this property.

Figure 4 shows the open porosity at 120 days curing time, for mortars made with different types and dosages

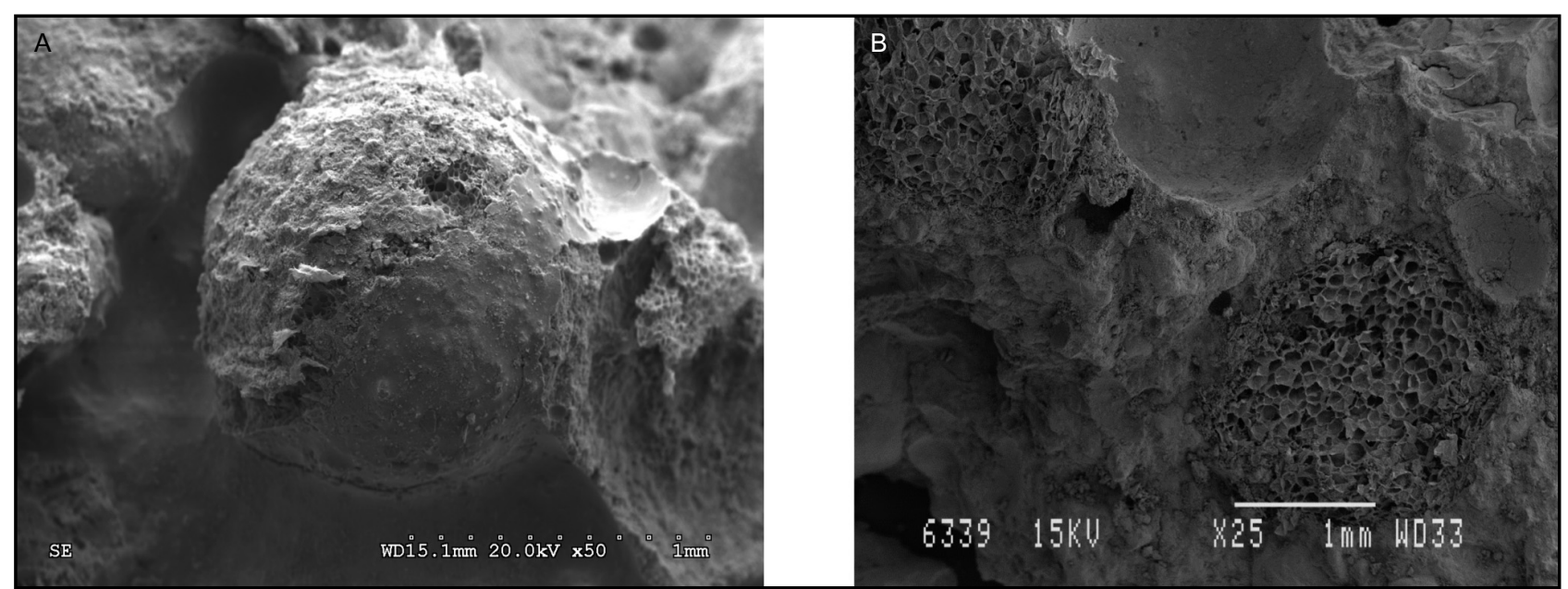

Figura 3. Imágenes SEM de morteros fabricados con EPS. A) Mortero con partícula de EPS sin romper. B) Mortero con partícula de EPS rota por el proceso de preparación de la muestra, quedando expuesta al agua la estructura interna de la espuma.

Figure 3. Electron microscope images of mortars made with EPS. A) Mortar with EPS particle without break. B) Mortar with EPS particle broken by the sample preparation process. It can be seen the internal structure of the foam. 


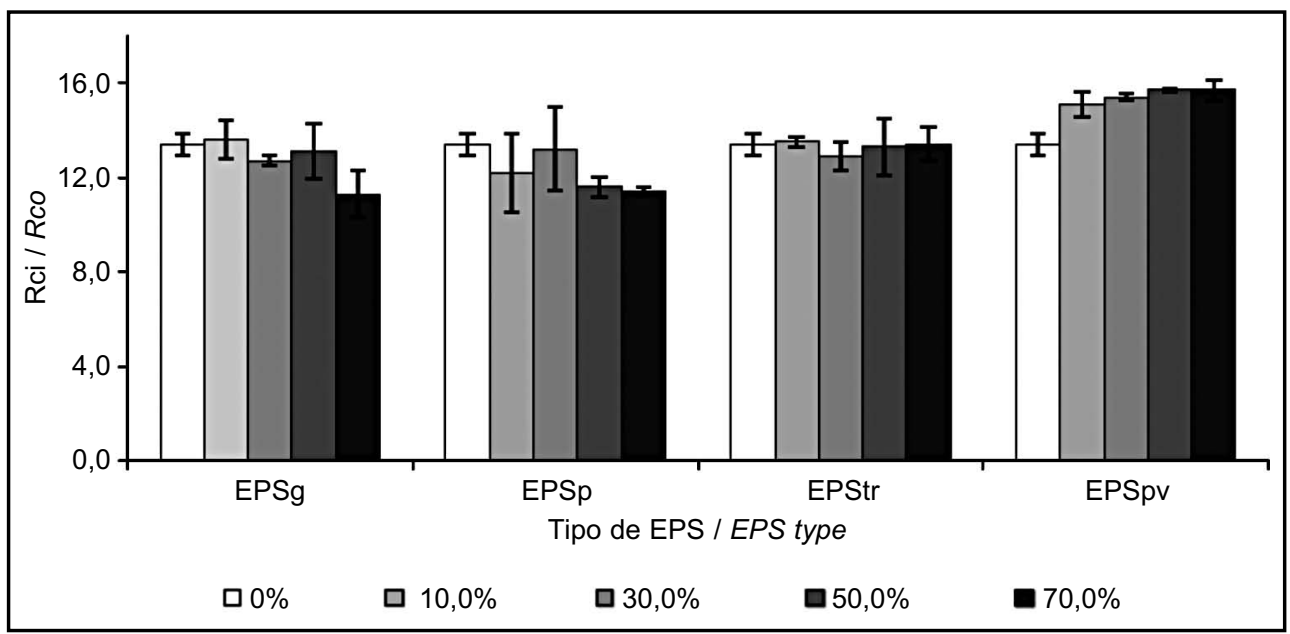

Figura 4. Porosidad abierta. a 120 días de curado, en función del porcentaje y tipo de EPS, junto con el intervalo de confianza para el $95 \%$ de probabilidad.

Figure 4. 120 days open porosity as a function of the percentage and type of EPS in mortar, with the $95 \%$ confidence interval.

y dosificaciones de EPS, así como los intervalos de confianza para el $95 \%$ de probabilidad. Para el EPSg, solo los morteros fabricados con el $70 \%$ muestran porosidades inferiores al patrón. En el caso del EPSp a partir del $50 \%$ se obtienen claras reducciones. Para el EPStr no se encuentran diferencias significativas entre las porosidades de los morteros. Todos los morteros fabricados con EPSpv muestran porosidades significativamente mayores que las del mortero patrón. Esta mayor porosidad se podría justificar con la escasa trabajabilidad de estos morteros así como con la morfología de este residuo, que como se observa en la Figura 5 presenta forma irregular y estructura abierta provocada en el proceso de triturado del EPS.

Las Figura 6 muestra la porosidad abierta, a 120 días de curado, expresada como la relación entre la porosidad of EPS, as well as 95\% confidence interval. In mortars made with EPSg, only the mortars made with $70 \%$ show open porosity lower than control mortar. In the case of EPSp from $50 \%$ clear reductions are obtained. For EPStr, significant differences were not found between the open porosity of the mortars. All mortars made with EPSpv show significantly higher porosity than the control mortar. This higher porosity could be justified with the low workability of these mortars as well as the morphology of this residue. This type of EPS, as shown in Figure 5 has an irregular and open structure caused in the grinding process of the EPS.

The Figure 6 shows the open porosity at 120 days curing time, expressed as the ratio of the porosity of the

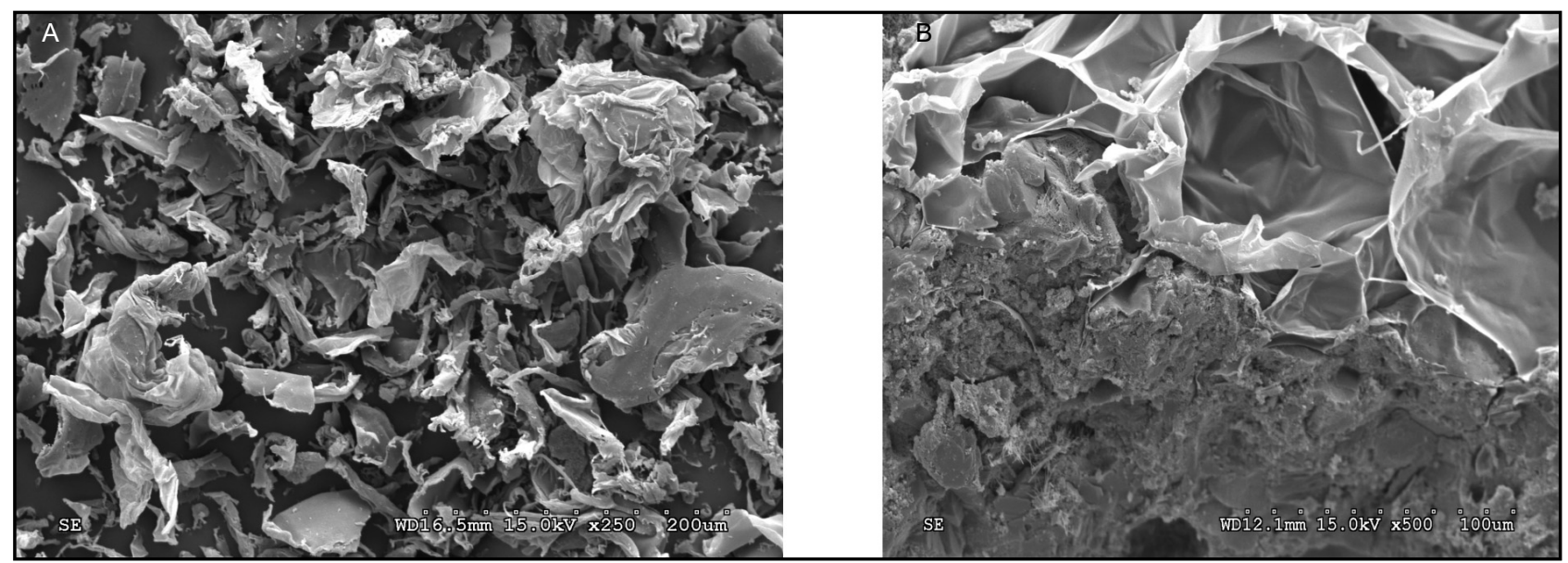

Figura 5. Imágenes SEM. A) Morfología del residuo EPSpv. B) Mortero fabricado con EPSpv.

Figure 5. Electron microscope images. A) Morphology of EPSpv waste. B) Mortar made with EPSpv. 
del mortero con EPS y aditivo (Pi) entre el valor de la porosidad obtenido para el mortero patrón, $0 \%$ EPS y $0 \%$ aditivo (Po). En la Figura 6A aparece la porosidad para morteros fabricados con distintos porcentajes de EPStr y aditivo aireante (A). En ella se puede observar que todos los morteros fabricados con este aditivo presentan porosidades menores que el mortero patrón. Al aumentar el porcentaje de aditivo aireante, así como la dosificación de EPS, no se observan cambios significativos en la porosidad. En la Figura 6B se muestra la porosidad para morteros fabricados con retenedor $(R)$ y EPStr. De nuevo, no se observan marcadas diferencias al modificar el porcentaje de retenedor o la dosificación de EPS. En los morteros sin EPS el retenedor no modifica la porosidad. La presencia de EPS en los morteros con retenedor disminuye la porosidad. La Figura 6C muestra la porosidad para morteros fabricados con distintos porcentajes de EPStr y aditivo fluidificante (F). De nuevo, en la mayoría mortar with EPS and additive (Pi) by the value of the porosity obtained for the control mortar, 0\% EPS and $0 \%$ additive $(\mathrm{Po})$. Figure $6 \mathrm{~A}$ shows the open porosity of mortars made with different percentages of EPStr and air-entraining agent additive (A). It can be seen that all mortars made with this additive have open porosity lower than the control mortar. There are no significant changes in porosity by increasing the percentage of airentraining agent and the EPS dosage. Figure $6 B$ shows the open porosity of mortars made with water retainer additive ( $R$ ) and EPStr. Again, there are no marked differences by changing the percentage of water retainer additive or the EPS dosage. The water retainer additive not changes the open porosity in mortars without EPS. The EPS in mortars made with water retainer additive decreases the open porosity. Figure $6 \mathrm{C}$ shows the open porosity of mortars made with different percentages of EPStr and superplasticizer additive (F). Once again, in

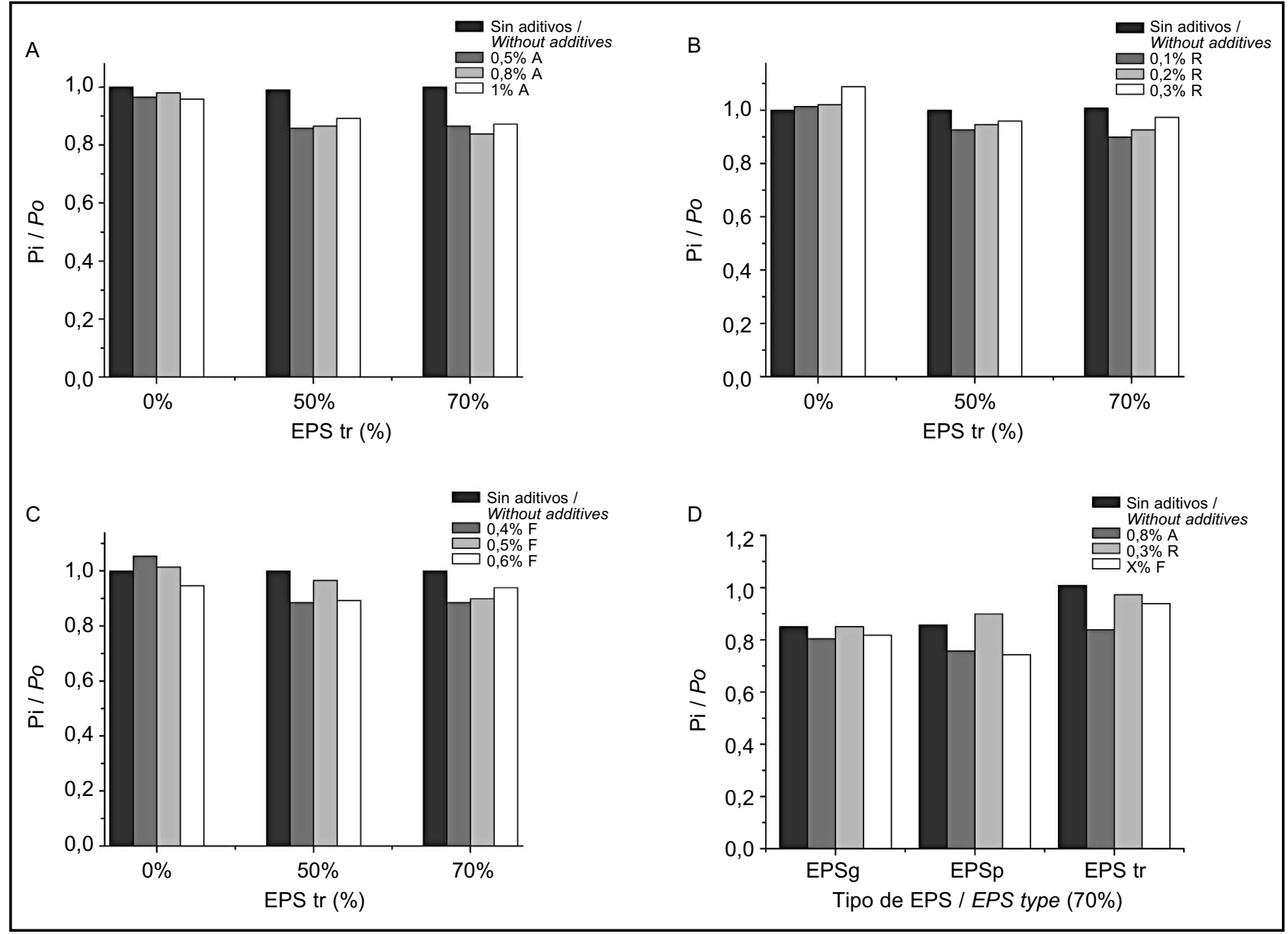

Figura 6. Porosidad abierta a 120 días de curado, expresada como relación Pi/Po (Pi: Porosidad abierta para un mortero dado; Po: Porosidad abierta para el mortero patrón. (0\% EPS. $0 \%$ aditivos)). A) Morteros fabricados con EPStr y aditivo aireante (A). B) morteros fabricados con EPStr y aditivo retenedor (R). C) Morteros fabricados con EPStr y aditivo fluidificante (F). D) Morteros fabricados con $70 \%$ de diferentes tipos de EPS y aditivos, siendo el valor X\% F de 0,1\% para EPSg, 0,9\% para EPSp y $0,5 \%$ para EPStr. Figure 6. 120 days open porosity expressed as a ratio Pi / Po (Pi: Open porosity for a given mortar. Po: Open porosity for control mortar. (0\% EPS. $0 \%$ additive)). A) Mortars made with EPStr and air-entraining agent (A). B) Mortars made with EPStr and water retainer additive (R). C) Mortars made with EPStr and superplasticizer additive (F). D) Mortars made with different EPS types and additives. In all cases $70 \%$ EPS dosage was used. The value of X\% F is $0.1 \%$ for EPSg $0.9 \%$ for EPSP and $0.5 \%$ for EPStr. 
de los casos no se observan grandes diferencias al modificar el porcentaje de fluidificante o la dosificación de EPS. Los morteros fabricados sin EPS experimentaron exudación debida a la presencia del aditivo, lo que provocó valores anómalos de porosidad. En morteros con EPS, la presencia del fluidificante permite obtener morteros menos porosos. Se puede concluir que para los morteros fabricados con EPStr, la presencia de cualquiera de los tres aditivos estudiados permite reducir la porosidad de los mismos, respecto al mortero patrón, así como respecto a los morteros con EPS sin aditivos. Finalmente, la Figura 6D muestra la influencia del tipo de EPS sobre la porosidad de morteros fabricados con aditivos y $70 \%$ de EPS. En todos los casos se obtienen porosidades inferiores a las del patrón. Para los morteros con EPSg se obtienen reducciones de porosidad similares para los tres aditivos. Para los morteros con EPSp los aditivos aireante y el fluidificante ofrecen las mayores reducciones de porosidad. El comportamiento de los morteros con retenedor se puede justificar por la menor consistencia que presentan estos, como se puede comprobar en la Tabla 5. Finalmente en los morteros fabricados con EPStr, la mayor reducción de porosidad se consigue con el aireante. En general, el EPStr es el tipo de EPS que provoca menor reducción de la porosidad. Se puede concluir que el uso de los aditivos estudiados en morteros con EPS permite reducir su porosidad abierta respecto al mortero patrón y a los morteros sin aditivos, hecho que resulta beneficioso para la durabilidad de los mismos. Esta afirmación se fundamenta en que la presencia de aditivo permite obtener morteros más homogéneos, lo que favorece que el EPS produzca una mayor interrupción de la red de poros.

Finalmente, se muestran los resultados obtenidos de la medida del coeficiente de absorción acústica a incidencia normal mediante el tubo de impedancia para morteros sin y con aditivos. En la Figura 7 se ha representado el coeficiente de absorción acústica, en función de la frecuencia, medida en Hz. En la Figura 7A se muestra dicho coeficiente para morteros amasados con distintos porcentajes de EPSpv, y en la Figura 7B se muestra este coeficiente para morteros con un $70 \%$ de distintos tipos de EPS. En ellas se puede observar que apenas existe variación en el coeficiente de absorción tanto al variar el porcentaje como el tipo de EPS, siendo el valor de este parámetro en todos los casos cercano a cero. Por tanto de ellas se puede deducir que dichos morteros son materiales muy poco absorbentes. En las Figuras 7C y 7D aparece la variación del coeficiente de absorción acústica en morteros que contienen aditivos. En la $7 \mathrm{C}$, se ha mantenido constante el porcentaje de EPS y la cantidad de aditivo aireante $(A)$, y se ha variado el tipo de EPS, y en la $7 D$, se ha variado el tipo de aditivo en morteros amasados con un $70 \%$ de EPSg. Ninguno de estos cambios provoca una variación significativa en el coeficiente de absorción acústica. most cases there are not large differences by changing the percentage of the superplasticizer additive or the EPS dosage. The mortars made without EPS underwent bleeding due to the presence of the additive, resulting in anomalous values of open porosity. In mortars with EPS, the presence of superplasticizer additive allows obtain mortars with less open porosity. In conclusion, for mortars made with EPStr, the presence of any of the three additives studied reduce their open porosity compared to control mortar and compared to EPS mortars without additives too. Finally, the figure $6 D$ shows the influence of EPS type in open porosity of mortars made with additives and $70 \%$ of EPS. In all cases, lower porosity is obtained compared to control mortar. For mortars with EPSg the reductions in open porosity obtained are similar for the three additives. The air entraining agent and the superplasticizer show the greatest reductions in open porosity for mortars with EPSP. The behaviour of mortars made with water retainer additive can be justified by their lower consistence, as can be seen in table 5. Finally, in mortars made with EPStr, the greatest reduction of open porosity is showed for mortars made with air-entraining agent. In general, the EPStr is the type of EPS that causes less reduction in open porosity. It can be concluded that the use of the three types of additives studied can reduce the open porosity in mortars with EPS, compared to control mortar and EPS mortar without additives. Therefore the use of these additives improves the durability of EPS mortars. It is due to the presence of additive allows obtain more homogeneous mortars that make to the EPS disrupt the pores network.

Finally, the results of the normal incidence sound absorption coefficient using the impedance or Kundt's tube for mortars made with and without additives. In figure 7 is shown the absorption coefficient versus the frequency, measured in $\mathrm{Hz}$. Figure $7 \mathrm{~A}$ shows this coefficient for mortars with different percentages of $E P S p v$, and figure $7 B$ shows this coefficient for mortars with $70 \%$ of different types of EPS. In this figures can be seen that practically not exist variation in the absorption coefficient by varying both the percentage and type of EPS. The value of this parameter is near to zero in all cases. They can see that there is little variation in the absorption coefficient by, where the value of this parameter in all cases closes to zero. Therefore it can be deduced that these mortars are slightly absorbent materials. Figures $7 C$ and $7 D$ show the variation of sound absorption coefficient in mortars containing additives. In figure $7 C$ the EPS percentage as well as the amount of air-entraining agent has remained constant, and has changed the type of EPS. Figure $7 D$ type of additive has changed in mortars made with $70 \%$ EPSg. None of these changes causes a significant variation in the absorption coefficient. 


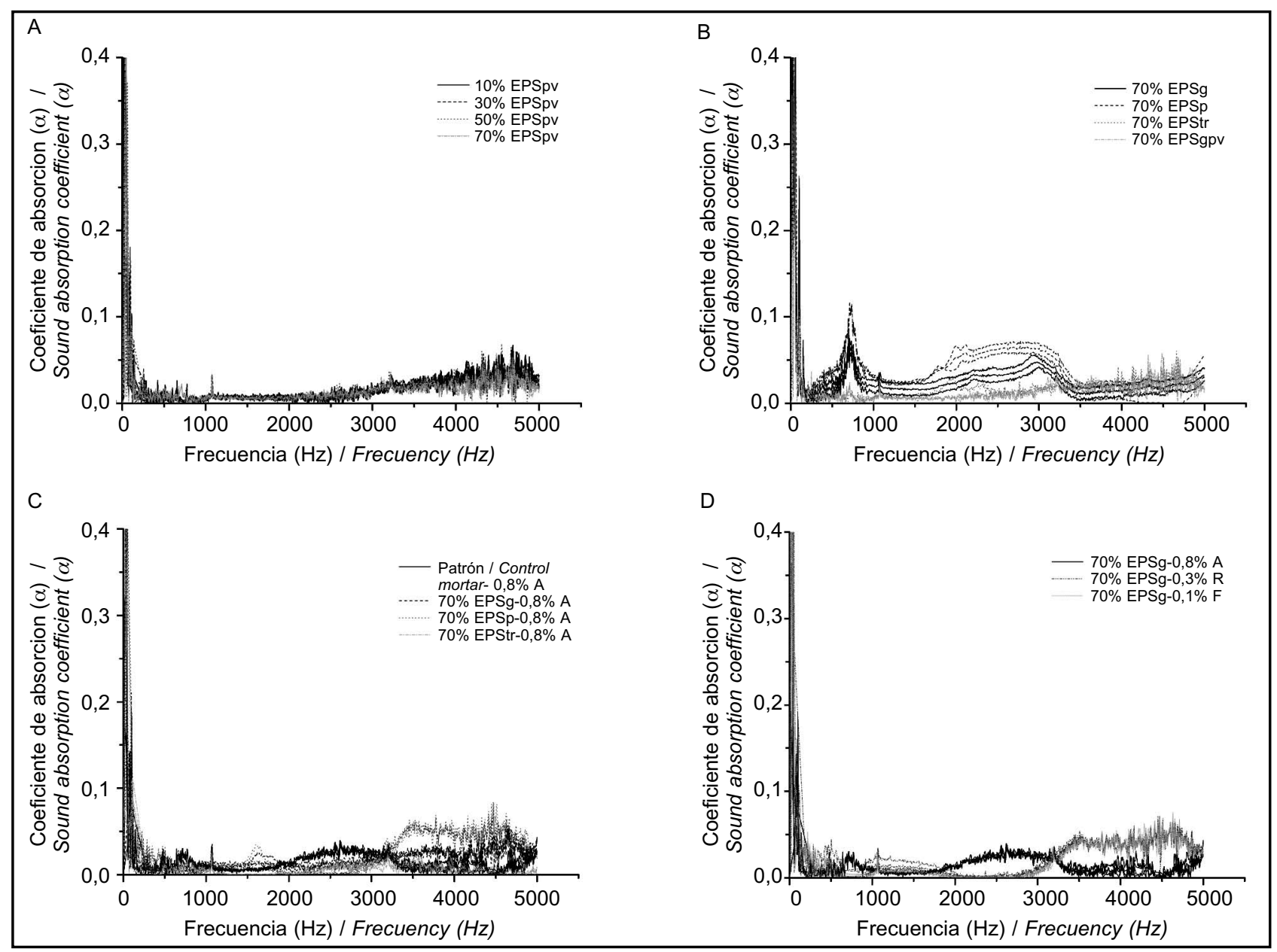

Figura 7. Coeficiente de absorción acústica a incidencia normal en función de la frecuencia medida en $\mathrm{Hz}$. A) Morteros amasados con EPSpv en distintas dosificaciones. B) Morteros con un 70\% de distintos tipos de EPS. C) Morteros fabricados con $70 \%$ de diferentes tipos de EPS y $0,8 \%$ de aditivo aireante. D) Morteros fabricados con $70 \%$ de EPSg y distintos tipos de aditivos.

Figure 7. Normal incidence sound absorption coefficient versus the frequency measured in $\mathrm{Hz}$. A) Mortars made with different percentages of EPSPV. B) Mortars made with 70\% of different types of EPS. C) Mortars made with 70\% of different types of EPS and $0.8 \%$ air entraining agent. D) Mortars made with $70 \%$ EPSg and different types of additives.

\section{CONCLUSIONES}

Los resultados obtenidos en este trabajo permiten extraer las siguientes conclusiones:

Existe una correlación negativa entre el aumento en la dosificación del EPS y la consistencia. Los morteros más trabajables son los fabricados con EPSg, evidenciando la influencia del tamaño del EPS en esta propiedad. La presencia de aditivos la mejora, permitiendo obtener morteros con mayor dosificación de EPS.

El aumento en la dosificación de EPS provoca un aumento del aire ocluido en el mortero en cantidades variables en función de la geometría de las partículas. Este aumento no logra contrarrestar la pérdida de trabajabilidad. La presencia de EPS en los morteros reduce el efecto de los aditivos en esta propiedad, excepto para el aditivo fluidificante.

\section{CONCLUSIONS}

The following conclusions can be drawn from the above findings:

There is a negative correlation between the increase in the EPS dosage and consistence. Mortars made with EPSg are the most workable, showing the influence of the EPS size in this property. The presence of additives improves the workability allowing manufacture mortars with higher EPS dosage.

The increase in the EPS dosage causes a rise in the air content in the mortar in varying amounts depending on the geometry of the particles. This increase cannot offset the loss of workability. The presence of EPS in mortars reduces the effect of additives on this property, except for the superplasticizer additive. 
La densidad del mortero fresco se reduce al aumentar el contenido de EPS en el mortero y conforme disminuye su tamaño de partícula.

La resistencia a compresión disminuye al aumentar el contenido de EPS, siendo siempre significativamente menor que la resistencia del mortero patrón, debido tanto a la reducción de la densidad del mortero endurecido como de la trabajabilidad, que implica la obtención de morteros menos homogéneos y más disgregados. Los valores alcanzados no son adecuados para los requerimientos mecánicos de los morteros convencionales. Sin embargo, cumplen los requisitos para los morteros de revoco, enlucido y de albañilería. Existen pocas variaciones en la resistencia a compresión de los morteros tanto en función de la cantidad de EPS como de aditivo. Para un mismo tipo de aditivo, no se detecta una influencia clara del tipo de EPS.

La presencia de EPS reduce significativamente la resistencia a flexión. El uso de aditivos no consigue mejorar esta propiedad.

El elevado valor obtenido en la absorción de agua de los morteros con EPS no es exclusivamente atribuible a la microestructura de la pasta, si no al tipo de muestra utilizada para el ensayo.

La porosidad de los morteros fabricados con EPS sin aditivos ofrece valores similares a los del mortero patrón y se ve claramente influenciada por la morfología del EPS. La presencia de cualquiera de los tres aditivos estudiados permite reducir la porosidad de los morteros fabricados con EPS, independientemente de la dosificación y el tipo.

Respecto al comportamiento acústico de estos morteros, se puede apreciar cómo apenas existe variación en el coeficiente de absorción a incidencia normal, independientemente del porcentaje y el tipo de EPS. El valor de este coeficiente para estos morteros oscila en torno a cero, valores que no se modifican al emplear aditivos. Estos resultados confirman que son materiales muy poco absorbentes.

\section{AGRADECIMIENTOS}

Las autoras desean agradecer al Ministerio Español de Ciencia e Innovación la financiación del proyecto BIA2007-61170, en el marco del cual se ha realizado el presente trabajo, y la concesión de la beca FPI (BES2009-012166) a Verónica Ferrándiz Mas que le permite desarrollar su Tesis Doctoral, de la que el presente trabajo forma parte.

También desean agradecer a la empresa Holcim Morteros, S.A., el suministro del cemento y los aditivos necesarios para la realización de este estudio.
The bulk density of fresh mortar is reduced by increasing EPS content in the mortar and by decreasing its particle size.

The compressive strength decreases with the increase of the EPS content, being always significantly less than the control mortar strength due to the dry bulk density and the workability, which involves obtaining less homogeneous and disintegrated mortars. The values obtained are not suitable for the mechanical requirements of conventional mortars. However this mortars show mechanical properties suitable for use as masonry mortars, stucco and plaster. There are few variations in compressive strength in mortars as in terms of the EPS amount as additive amount. For mortars made with the same type of additive there is not a clear influence of EPS type.

The presence of EPS in mortars reduces significantly the flexural strength. The use of additives does not get to improve this property.

The high value obtained in the water absorption of mortars with EPS, is not exclusively attributable to the microstructure of the cement paste. This fact is due to the type of sample used for testing.

The mortars with EPS and without additives porosity provides values similar to those of the control mortar and is clearly influenced by the morphology of EPS. The presence of any of the three additives studied, allows reducing the porosity of the mortars made with EPS, regardless of dosage and type.

Regarding the acoustic behaviour of these mortars, it can see how there is little variation in the normal incidence sound absorption coefficient, regardless the EPS percentage and type. The value of this coefficient for these mortars oscillates around zero, values that are not modified by using additives. These results confirm that there are slightly absorbent materials.

\section{ACKNOWLEDGEMENTS}

The authors wish to thank the Spanish Ministry of Science and Innovation for the BIA2007-61170 project funding, in the framework of which this work has been done, and the FPI scholarship (BES-2009-012166) award to Veronica Ferrándiz Mas which allows her to develop her doctoral thesis, which this present work is part.

The authors also wish to thank Holcim Morteros SA, for the supply of cement and additives necessary for the carrying out of this study. 


\section{BIBLIOGRAFÍA / BIBLIOGRAPHY}

(1) Gatani, M; Argüello R.; Sesín S.: "Effect of chemical treatments on the mechanical properties of peanut shell and cement blends", Mater. Construcc., Vol. 60, no 298, (2010), pp. 137-147, doi: 10.3989/mc.2010.46908

(2) Guzmán, A.; Gutiérrez, C.; Amigó, V.; Mejía de Gutiérrez, R.; Delvasto, S.: "Pozzolanic evaluation of the sugar cane leaf", Mater. Construcc., Vol. 61, no 302, (2011), pp. 213-225, doi: 10.3989/mc.2011.54809.

(3) Del Rey, R.; Alba, J.; Ramis, J.; Sanchís, V. J.: "New absorbent acoustic materials from plastic bottle remnants" Mater. Construcc., Vol. 61, no 304, (2011), pp. 547-558, doi: 10.3989/mc.2011.59610.

(4) Short, A.; Kinniburgh, W.: "Lightweight Concrete", Applied Science Publishers, 3rd ed., London (1978).

(5) Sussman, V.: "Lightweight plastic-aggregate concrete", Journal of American Concrete Institute, vol. 72 (1975), pp. 321-323.

(6) Sussman, V.; Baumann, G. H.: "Expanded polystyrene beads lighten the load", Soc. Plastic Eng. J., vol. 28 (1972), pp. 18-21.

(7) Cook, D. J.: Expanded polystyrene concrete, en Swamy, R.N. (ed.), "Concrete Technology and Design", New Concrete Materials, vol. 1, Surrey University Press, London, pp. 41-69 (1983).

(8) Bagon, C.; Frondistou-Yannas, S.: "Marine floating concrete made with polystyrene expanded beads", Mag. Concr. Res., vol. 28 (1976), pp. 225-229. http://dx.doi.org/10.1680/macr.1976.28.97.225

(9) Perry, S. H.; Bischoff, P. H.; Yamura, K.: "Mix details and material behaviour of polystyrene aggregate concrete", Mag. Concr. Res., vol. 43 (1991), pp. 71-76. http://dx.doi.org/10.1680/macr.1991.43.154.71

(10) Bischoff, P. H.; Yamura, K.; Perry, S. H.: "Polystyrene aggregate concrete subjected to hard impact", Proceedings of the Institution of Civil Engineers part 2-Research and Theory, 89 (1990), pp. 225-239.

(11) Ganesh Babu, K.; Saradhi Babu, D.: "Behaviour of lightweight expanded polystyrene concrete containing silica fume", Cem. Concr. Res., vol. 33 (2003), pp. 755-762. doi:10.1016/S0008-8846(02)01055-4.

(12) Ganesh Babu, K.; Saradhi Babu, D.; "Properties of lightweight expanded polystyrene aggregate concretes containing fly ash", Cem. Concr. Res., vol. 35 (2005), pp. 1218-1223. doi:10.1016/j.cemconres.2004.11.015.

(13) Tang, W. C.; Lo, Y.; Nadeem, A.: "Mechanical and drying shrinkage properties of structural-graded polystyrene aggregate concrete", Cem. Concr. Comp., vol. 30 (2008), pp. 403-409. doi:10.1016/j.cemconcomp.2008.01.002.

(14) Bouvard, D.; Chaix, J. M.; Dendievel, R.; Fazekas, A.; Létang, J. M.; Peix, G.; Quenard, D.: "Characyerization and simulation of microestructure and properties of EPS lightweight concrete", Cem. Concr. Res., vol. 37 (2007), pp. 1666-1673. doi:10.1016/j.cemconres.2007.08.028

(15) Madandoust, R.; Ranjbar, M. M.; Mousavi, S. Y.: "An investigation on the fresh properties of self-compacted lightweight concrete containing expanded polystyrene", Constr. Build. Mater., vol. 25 (2011), pp. 3721-3731. doi: 10.1016/j.conbuildmat.2011.04.018

(16) Laukaitis, A.; Zurauskas, R.; Keriene, J.: "The effect of foam polystyrene granules on cement composite properties", Cem. Concr. Comp., vol. 27 (2005), pp. 41-47. doi:10.1016/j.cemconcomp.2003.09.004

(17) García Santos, A.: PPF-reinforced, ESP-lightened gypsum plaster, Mater. Construcc., vol. 59, no 293 (2009), pp. 105-124, doi: 10.3989/mc.2009.41107

(18) Wu, H.C.; Sun, P.: "New building materials from fly ash-based lightweight inorganic polymer", Constr. Build. Mater., vol. 21 (2007), pp. 211-217. doi:10.1016/j.conbuildmat.2005.06.052.

(19) UNE-EN 196-1:2005: "Métodos de ensayo de cementos. Parte 1: Determinación de las resistencias mecánicas".

(20) http://www.anape.es/index-producto.html

(21) UNE-EN 1015-3:2007: "Método de ensayo de los morteros de albañilería. Parte 3: Determinación de la consistencia del mortero fresco (por la mesa de sacudidas)".

(22) UNE-EN 1015-7:1999: "Métodos de ensayo de los morteros de albañilería. Parte 7: Determinación del contenido en aire en el mortero fresco".

(23) UNE-EN 1015-6: 1999/A1:2007: "Métodos de ensayo de los morteros de albañilería. Parte 6: Determinación de la densidad aparente del mortero fresco".

(24) UNE-EN 1015-10:2000: "Métodos de ensayo de los morteros de albañilería. Parte 10: Determinación de la densidad aparente del mortero endurecido".

(25) ISO 10534, "Acoustics-determination of sound absorption coefficient and impedance or admittance by the impedance tube. Part I (1996): Standing wave ratio method. Part II (1998): Transfer-function method".

(26) UNE-EN 998-1: 2010: "Especificaciones de los morteros para albañilería. Parte 1: Morteros para revoco y enlucido".

(27) UNE-EN 998-2: 2004: "Especificaciones de los morteros para albañilería. Parte 2: Morteros para albañilería". 